\title{
BANK REGULATIONS AND LOAN CONTRACTS ${ }^{\dagger}$
}

\author{
Romulo Magalhaes * \\ Universidad Carlos III de Madrid (Dep. of Business Administration) and \\ Banco Central do Brasil \\ e-mail: romulo.magalhaes@bcb.gov.br
}

\author{
Josep A. Tribó \\ Universidad Carlos III de Madrid \\ Department of Business Administration \\ e-mail: joatribo@emp.uc3m.es
}

\begin{abstract}
$\underline{\text { Abstract }}$
This study examines empirically how bank regulations adopted in lender countries influence the characteristics of loan contracts, using a sample of 46,453 loans made by 278 large commercial banks around 39 countries, to borrowers in 83 countries, in the period from 1998 to 2006. Our findings indicate that the stringency of capital regulations have an inverse Ushaped relationship with priced risk characteristics (spread and maturity) of loan contracts. In addition, more powerful official supervision is associated with riskier loan contracts. Both official supervisory power and private monitoring work as substitutes to capital regulation to reduce the (priced) risk measures of loan contracts when capital stringency is low. For higher capital stringency, supervision and private monitoring complement capital regulation in reducing loan contracts risk measures. Finally, we found that a country's degrees of legal enforcement and bank industry competition complement capital and private monitoring regulations to improve risk characteristics of loan contracts. The evidence highlights the importance of how bank lending practices are affected by bank regulations and their interactions with themselves and other institutional country factors.
\end{abstract}

JEL Classification:.G21, G28, G32

Keywords: Banks, Regulation, Credit, Risk, Bank Lending, Syndicated Loans

\footnotetext{
$\dagger$ The authors wish to thank the financial support of the Ministerio de Ciencia y Tecnologia from Spain (grant \# SEJ2006-09401). The usual disclaimers apply.

* Corresponding author.
} 


\section{Introduction}

The existence of banks as financial intermediaries and the functioning of the banking system are argued to be of great importance in determining a country's economic growth and stability (Allen and Gale, 2000; Levine, 2006). More specifically, the credit channel plays a pivotal role in the transmission of the monetary policy, which is a basic element for achieving a sustained economic growth (e.g., Bernanke and Gertler, 1995), as well as financial stability. Governments and national institutions all over the world are aware of the important role played by financial institutions and impose several regulations on the banking sector. More formally, the need for regulation is grounded on two basic reasons: first, the risk of a systemic crisis that would spread along all the economy; second, the inability of depositors to monitor banks (Santos, 2001). This study is interested in looking at how the functioning of credit markets is affected by bank regulations.

The recent international financial crisis triggered a necessary and urgent debate on the restructuring of financial systems. The roles that prudential regulation on capital requirements, official supervision and market discipline should play in achieving the ultimate regulations' purposes of guaranteeing financial stability and supporting economic growth are at the core of the discussion. Despite the current urgency of the issue, such discussion is already in place at least since the revision of the 1988 Basel Capital Accord, which led to a revised framework, the Basel II Capital Accord (Basel Committee, 2004). This accord establishes three bank regulatory pillars, representing capital requirements, supervisory review process, and market discipline. The effort devoted by Basel II in achieving bank regulatory convergence is not without criticisms, such as the high reliance that Basel II puts on supervisors to ask banks to hold capital above the minimum required. The critics ${ }^{1}$ see this reliance as an attempt to replace the market by supervisors or by the complicated formulae proposed by Pillar I. Also, the international standard status of Basel II and the widespread trend for its adoption make such an emphasis on supervision a challenge to the ability of developing countries in spending high resources on more sophisticated bank supervisory systems. Moreover, the emphasis on supervision implies the assumption that the public interest is to prevail, which could not be the case in weak institutional environments, where high supervisory discretion could lead to venal and systematic corruption. On the top of that, the current global financial crisis reveals serious problems with the mix between capital regulation, supervision and market discipline. The failure of that mix to avoid such a big crisis

\footnotetext{
${ }^{1}$ For instance, see SFRC (1999), Rochet (2003), Kane (1997, 2002, 2004), Herring (2004).
} 
is leading many officials and politicians to advocate for a movement towards more regulation and supervision, as well as the critics to Basel II are probably revaluating their views.

Our study contributes to the debate on the efficiency of the three mentioned bank regulatory mechanisms by adding empirical evidence on their relative importance, the complementarities among them, as well as their interactions with the institutional environments they are inserted in. Our purpose, similarly to Barth et al (2006), is to achieve a better understanding of the forces influencing bank regulatory and supervisory choices and how these are translated into the credit policies adopted by financial institutions. We provide evidence of the effects of the aforementioned broad regulations on loan characteristics such as spread and maturity, using a large sample composed of syndicated loan contracts initiated by 278 large commercial banks around 39 countries, to borrowers in 83 countries, in the period from 1998 to 2006.

The main results indicate that the stringency of capital regulations have an inverse Ushaped relationship with the priced risk measures of loan contracts. Regarding bank supervision, we find that official supervisory power is associated with riskier loan contracts. Both official supervisory power and private monitoring interact negatively with capital stringency to reduce risk term of loans (decrease spread and increase maturity). Given the nonlinear relationships between capital stringency and risk measures (inverse U-shaped with spread and direct U-shaped with maturity) we found that official supervisory power and private monitoring interact differently with capital stringency to influence risk measures of loan contracts, depending on different levels of capital stringency. For low levels of the latter, both supervisory power and private monitoring are substitutes to capital stringency when reducing the risk measures of loans. For high levels of capital stringency, supervisory power and private monitoring are complements to capital to reduce the risk terms of loans. Evidence on interactions between regulations and other country-level factors points that capital stringency decreases priced risk loan characteristics (decreases spread and increases maturity) especially in countries with high levels of legal enforcement, financial development and competition.

The reminder of the article is structured as follows. Section II describes the related literature and empirical hypotheses to be tested. Section III describes the sample and variables used to conduct our empirical analyses. Methodology and results are presented in Section IV. The final section of the article presents the main conclusions of this research and offers a discussion of the significance of our results. 


\section{Related Literature}

The purpose of this empirical study is twofold: (i) to investigate the individual effects of bank regulations regarding capital requirements, supervisory power and private monitoring of banks on the characteristics of loan contracts, and (ii) to examine possible interactions between these three broad bank regulations and other institutional country mechanisms affecting the characteristics of loans. Accordingly, in this section we first briefly review the main theories on the separate influence of the three bank regulations on bank lending. Then, we present the theoretical arguments that point to possible interactions, substitutability, complementarities, and trade-offs between those regulations themselves and other mechanisms affecting bank lending, such as competition in the bank industry and country legal and financial systems development. We then concentrate on the empirical related literature. Finally, we propose the empirical hypotheses to be tested in our analysis.

\section{Bank Capital Regulation}

Despite the lack of consensus on whether and how banks need to be regulated, two justifications for regulating banks are often presented: the risk of a systemic crisis and the inability of depositors to monitor banks (Santos, 2001). The use of a deposit insurance scheme by governments is probably the most adopted proposal to avoid bank runs. Although very successful in protecting banks from runs, deposit insurance is not without a cost, as it implies moral hazard on the part of banks. That is because the deposit insurance provider bears the risk to protect depositors from losses, which inhibits depositors' incentive to monitor banks. The consequence is an increase in the risk taking incentives of banks. If the insurance premium is not fairly priced, the risk taking incentives are even higher, as the full cost of risk is not internalized by the bank. Such risk-shifting incentive cannot be removed by charging fairly priced insurance premiums given that information asymmetry makes them impossible to be computed (Chan, Greenbaum and Thakor, 1992), or undesirable from a welfare point of view (Freixas and Rochet, 1995). In this context, bank capital regulation arises as a mechanism to prevent bank failures and their potential externalities, by influencing bank risk taking. Nevertheless, theoretical research on the effects of capital regulations on bank performance, risk and stability has produced contradictory results ${ }^{2}$. With respect to this research, a conclusion of VanHoose (2006) states that "the intellectual foundation for bank

\footnotetext{
${ }^{2}$ Santos (2001) and VanHoose (2006) provide comprehensive reviews of the theoretical literature on the effects of bank capital regulation on the risk-taking behaviour and solvency of banks.
} 
capital regulation in general and for the proposed Basel II system specifically is not particularly strong. Instead of expanding the scope and complexity of the current system of capital regulation, it may be time to contemplate alternative approaches to bolstering the safety and soundness of the banking system." We depart from VanHoose (2006)'s conclusion as a motivation to undertake this empirical research using a more comprehensive scope of bank regulation.

The empirical evidence of the effects of capital regulation on bank lending is not consensual. For instance, different analyses of the credit crunch occurred in the United States in the early 1990s produced contrasting results. Some studies conclude that the introduction of capital requirements resulted in a reduction in loan supply, as a consequence of increase in capital ratios. Peek and Rosengren (1995a, 1995b) conclude that a decrease in loan supply induced by capital regulation, together with lower loan demand caused the decline in lending. Similar evidence is offered by Brinkmann and Horvitz (1995), Furlong (1992), Haubrich and Wachtel (1993), Lown and Peristiani (1996) and Hiuri et al. (2002). The contrasting evidence comes from Berger and Udell (1994), who attribute the credit crunch to a decline in loan demand and to other factors affecting loan supply. Wagster (1999) also concludes that other factors excluding capital regulation generated the credit crunch in the U.S. His study looks at other countries and find mixed evidence. The review of Jackson et al. (1999) examines many studies looking at the effects of capital regulation on capital ratios and reaches a mixed conclusion: in the short term, banks reduce lending to adjust to a tightened capital requirement, but do not maintain higher capital ratios in the mid term. Ashcraft (2001), and Flannery and Rangan (2004) find little evidence of the influence of U.S. capital regulations on capital ratios, respectively for the 1980s and more recent years.

Concerning the effect of capital regulation on bank risk taking, the evidence is mixed as well, although the majority of studies point to an overall increase in risk after the implementation of the Basel I capital regulation framework. Hendricks and Hirtle (1997) find evidence in favour of risk reducing, but argue that the benefits are likely to be small, as most banks only slightly increase their capital ratios in response to capital regulations. On a sample of 98 U.S. bank holding companies in the 1975-1986 period, Furlong (1988) concludes that less risk-averse banks did not increase their asset risk in response to the introduction of capital regulation in the 1980s. Sheldon (1996) finds little evidence that Basel I capital regulation reduced asset risk on a cross-country sample in the 1987-1994 period. According to Jackson et al. (1999), a weakness of these two studies is that they do not control for many potential influences on bank risk-taking. Barth et al. $(2004,2006)$ minimize this problem by using a 
sample of survey data across 107 countries, which allows them to include controls for the effects that different country regulatory policies may produce in the functioning of banking systems. Their results regarding whether capital regulation induces banks to take less risk are mixed. Although they find that more stringent capital requirements are related to fewer nonperforming loans, they do not find a relation between stringent capital regulations and the likelihood of a banking crisis.

\section{Bank Supervision}

Under the public interest view of regulation ${ }^{3}$, bank supervision arises as an activity capable of overcoming inherent failures of financial markets. In such approach to regulation, bank supervisors have the proper incentives, abilities and the necessary powers to accomplish their purposes of ensuring safety and soundness of the banking system (Barth et al., 2006). More specifically, supervision plays a role in reducing excessive bank risk-taking and promoting bank performance and stability. In this view, powerful and independent supervisory agencies are desirable, in order to avoid regulators suffering the political pressure of bankers. By contrast, the private interest view assumes that supervisors may use their power to serve either their own private interests or the ones of bankers and politicians. The consequences of powerful supervision in this view are poor bank performance and increased corruption. Research on bank supervision is scarce and limited to few empirical studies and to the discussion of conceptual issues underlying the Basel II's proposal for the supervisory review process, known as Pillar II. By identifying implicit assumptions in some criticisms to the proposal of Pillar II (e.g. SFRC, 2001 and Hamalainen et al., 2003), VanHoose (2007) proposes a discussion on three conceptual issues underlying the appropriateness of the supervisory review process. The first issue refers to the question if rules are preferred over discretion in the supervisory process. It is raised by a common criticism that Pillar II proposal gives a lot of discretion to banks and supervisors, which could result in increased risk arbitrage and regulatory forbearance. The second issue is related to the first and asks how

\footnotetext{
${ }^{3}$ There are two approaches underlying the research on regulation. The public interest approach to bank regulation thinking considers that regulation serves to the public interest of improving social welfare, by boosting economic development, preventing systemic crises and protecting depositors. This approach assumes the existence of market failures and that governments have the incentives and capabilities to overcome those failures. Opposed to that view, the private interest approach arises by viewing regulation as a product, subject to supply and demand forces. In this view, the private interests of the regulator and bankers prevail over the public interest, when determining bank regulations. It is the case for political and/or regulatory capture, which can lead to venal and systematic corruption. In practice, it is reasonable to view regulations to experience a dynamic process of responding to different incentives along the time, fluctuating between the extreme approaches (Kane, 1997). See Barth et al. (2006, chapter 2) for a review on public and private interest approaches to regulation.
} 
tough a policy rule really should be. There is theoretical disagreement whether prompt closing troubled banks is an optimal supervisory policy ${ }^{4}$. The third conceptual issue refers to whether international coordination of regulatory and supervisory rules is appropriate. The existent research on this issue is scarce ${ }^{5}$.

Empirical evidence about the effects of supervision on bank lending and risk-taking is very limited. DeYoung et al. (2001) find that government supervisory examinations of large commercial banks produce new, value-relevant information. Although debt prices do not immediately reflect this information, the implied regulatory actions are priced by the market. Berger et al. (2000) compares the timeliness and accuracy of government assessments of bank condition against market evaluations. They find that supervisors and bond rating agencies both acquire some information that would help the other group forecast changes in bank condition. However, supervisory assessments and market indicators are not strongly interrelated. In addition, supervisory assessments are less accurate than either stock or bond market indicators in predicting future changes in performance. Both studies considered only large U.S. banking firms. By contrast, Barth et al. (2006) use a large sample of banks and countries, including emerging ones, to derive conclusions regarding the effectiveness of bank supervision. They find that empowering direct official supervision of banks does not boost bank development.

\section{Private Monitoring of Banks}

The reliance on the private monitoring of banks, a mechanism related to market discipline, is argued to be an alternative way to restrict excessive risk-taking behaviour of banks. From the private interest view of regulation, such reliance is argued to have a greater importance, as supervisors and regulators are assumed to succumb to bankers' and politicians' interests. Herring (2004) argues that "one of the principal merits of market discipline is that bank directors and managers are faced with the burden of proving to the market that the bank is not taking excessive risks rather than subjecting officials to the burden of proving, in a review process, that the bank is taking excessive risks." (pp. 365-366). Hamalainen et al. (2003) describe many potential social benefits of market discipline. Among the most important ones, we mention: first, the possible reduction in moral hazard resulting form deposit insurance; second, the threat of market discipline provides constant pressure on management to improve cost efficiency; third, if the market discipline process is faster than

\footnotetext{
${ }^{4}$ See Sleet and Smith (2000), Kocherlakota and Shim (2005) and Shim (2006)

${ }^{5}$ See Holthausen and Rønde (2005) and Dell'Aricia and Marquez (2006)
} 
regulatory actions, it may help regulators to screen "bad banks" from "good banks", and promote the aforementioned Herring (2004)'s shift of the burden of proof. Among the potential negative effects of market discipline, the most important is the possibility of a bank run resulting from reactions of fund suppliers to widespread perceptions of higher failure probabilities $^{6}$. Another undesirable effect is when market participants and regulators take misguided reactions as a consequence of persistent false market signals sent by fund suppliers. The market discipline concept applied to banking refers mainly to the reactions of fund suppliers - depositors, debt holders, shareholders - in order to induce banks to solve a perceived deterioration in bank solvency. These reactions may be the reduction in the amount that funds suppliers maintain in the bank, the maintenance of the same amount but at a higher rate of return, or the entire interruption of funds supply to the bank. Some conditions for fund suppliers to be able to engage in market monitoring are necessary, such as the existence of open and active markets capable to provide visibility of bank risk of insolvency to all fund suppliers, regulations promoting bank transparency and the release of correct information at appropriate times, and a no-bailout policy of depositors or banks (Flannery, 2001). Despite the variety of conclusions from the academic research regarding the relative effectiveness and desirability of relying on market discipline as a mechanism of bank regulation, VanHoose (2007) observes that Basel II has ignored the potentially useful signalling roles of market discipline. He warns that market discipline aspects of Basel II represent at best minimal innovations for most well-developed banking systems. However, he argues that countries with less developed banking systems are more likely to benefit from Basel II's pillar III recommendations.

Turning to the empirical evidence on market discipline in banking, the review of Flannery (1998) of mid 1990s research concludes for the existence of supporting evidence to a role for market discipline in supplementing regulatory supervision. This kind of evidence generally tests if suppliers of funds are able to perceive changes in banks' risk profiles. In this regard, Flannery and Sorescu (1996) show that investors can rationally distinguish among risks taken by U.S. banks, by looking at the spreads between yields on subordinated debt and treasury bonds with the same maturities as indicators of capital adequacy and predictors of bank condition. It is especially true if subordinated debt is perceived as not being guaranteed by the government. Distinguin et al. (2006) find evidence that market-based indicators can

\footnotetext{
${ }^{6}$ In the model of Chen and Hasan (2006), greater information transparency of banks tends to boost the likelihood of bank runs, unless bank informational disclosures clarify to depositors that the problem is idiosyncratic.
} 
help predicting the degree of bank stress, as long as the bank does not heavily rely on uninsured deposits. Morgan and Stiroh (2001) examine market spreads on new bonds issued by U.S. banks and bank holding companies in primary markets to conclude that debt markets provide clear signals of asset risk differentials across banks. In evaluating subordinated-debt spreads as indicators of bank risk, Evanoff and Wall (2001) conclude that these are better predictors of regulatory ratings than capital ratios.

\section{Mix and interactions between mechanisms}

Although the many criticisms to the proposed approaches of Basel II, its general framework of structuring bank regulation and supervision in three pillars - risk-based capital requirements, supervisory review and market discipline - is widely consensual and accepted. The basic assumption of this framework is that the three pillars will reinforce each other and result in effective improvements for bank safety and soundness. In other words, they are assumed to be complements. An obvious implicit assumption is that the intended result may not be achieved unless all pillars are sufficiently well designed and structured (VanHoose, 2007). Some authors, like Llewellyn and Mayes (2003), examined the conditions for market discipline and prompt corrective action to be complements. However, little research effort was dedicated to analyze joint interactions among the three regulatory mechanisms. Also, little effort was made by both the academic researchers and the Basel Committee to develop the second and third pillars, which raises concerns regarding the appropriateness of the proposals of Basel II in achieving its purposes. Next, we present the academic contributions to the issue of how the mechanisms of capital requirements, supervision and market discipline mix and interact, and the correspondent implications to bank behaviour.

\section{Substitutability}

Calem and Rob (1999) find a role for market discipline in reducing the risk-taking incentives of undercapitalized banks. Milne (2002) claims a role for ex post penalties imposed by supervisors in case capital requirements are not fulfilled. He argues that such a mechanism is likely to be more efficient in reducing risk-taking incentives than toughening capital requirements tied to asset risks. In their theory of bank capital based on the financial fragility as essential for banks to create liquidity, Diamond and Rajan (2000) also indicate a role for prompt corrective action, in the presence of deposit insurance. Dowd (2000) points that the problem of financial fragility introduced by Diamond and Rajan $(2000,2001)$ can be fully solved if banks keep a sufficient large capital cushion. Marini (2003) extends the analysis of Dowd (2000) to conclude that market-capitalized banks are also protected from insolvency 
crisis. The arguments of Dowd and Marini offer the conclusion that market-capitalized levels of bank capital can substitute for both supervision and deposit insurance.

\section{Contingent complementarity}

Campbell et al. (1992) provide interesting results on the combination of capital requirements and monitoring in the optimal contract: first, as bank assets' risk increases, it is optimal for depositors to increase both capital and monitoring, i.e., the mechanisms are complementary. Second, as incentive problems with monitors increase, depositors should increase capital requirements at the expense of monitoring, i.e., the mechanisms are substitutes.

\section{Complementarities}

Some studies explicitly incorporate the mechanisms of the three pillars of Basel II. The dynamic model of Estrella (2004) finds that higher capital requirements only partially align bank behaviour to regulator's objectives. Extra regulatory effort directed to less capitalized banks and market discipline alleviate the problem, although not sufficiently to attain the regulator's first best desired outcome. As proposed by the author, a complete alignment to the regulator's interest can be achieved if a regulatory commitment to an ex post penalty is applied. The comprehensive and ambitious study of Decamps et al. (2004) proposes a dynamic model based on continuous-time cash flows to examine interactions between the three pillars of Basel II. The authors interpret capital requirements as a closure threshold. They show that market discipline can be used to reduce the closure threshold, especially if there is a risk for regulatory forbearance. Regarding the second pillar, the authors suggest a mechanism of indirect market discipline, where supervisors can modulate the intensity of their interventions based on reliable signals given by market prices of the securities issued by banks. In his analysis of pillars II and III of Basel II, VanHoose (2007) argues that the market discipline pillar does not go far enough in the right direction, while the supervisory-process pillar goes too far in exactly the wrong direction. He suggests that "the market-discipline pillar would be significantly improved by requiring national regulators to begin studying the informational properties of market signals in bank debt markets for possible use in correctiveaction policies" (p. 32).

\section{Interaction between bank regulations and country-level governance}

There are some considerations concerning the interaction of bank regulations with other country-level aspects related to the economic and legal environments where banks operate. As previously mentioned, the idea that high reliance on market discipline can substitute for regulatory and supervisory power emerges from the private interest view of 
bank regulation. An important related issue is whether excessive reliance on market discipline is appropriate for countries with weak legal and financial systems, and poor accounting standards (Barth et al., 2006). The public interest view advocates for reliance on official supervisors to monitor the banking systems in weak institutional environments. It is argued that in such settings, great reliance on private monitoring leads to exploitation of small savers and consequently, to less bank development. The counter argument from the private interest view is that powerful supervisors are more likely to benefit private interests precisely in less institutionally developed countries. Caprio and Honohan (2004) go further and claim that for many reasons low developed countries may be better positioned to exercise market discipline: the lower complexity and the size of the banking and financial markets facilitate monitoring; the absence or low credibility of deposit insurance stimulates market monitoring; the presence of many foreign banks may result in more information disclosure. Barth et al. (2006) conclude that only empirical testing can resolve the debate. These authors offer a kind of reconciliation of bank supervision and market discipline when commenting the results of their empirical analysis: "[S]upervision works best when it facilitates market monitoring". Our study also offers a contribution in respect of this.

There is some evidence on the joint effects of bank regulations. Concerning the 1990s U.S. credit crunch, Furfine (2001) concludes that toughened supervision had a larger influence on banks' balance sheet choices than explicit capital requirements. Barrios and Blanco (2003) used different models to assess the response of bank capital to market forces versus capital constraints. They concluded that the 76 Spanish commercial banks in their sample were unconstrained by capital regulation between 1985 and 1991, as the market-based model better fitted the data. Similarly, Beatty and Gron (2001) find that the introduction of risk-based capital regulations did not influence the behaviour of 438 U.S. bank holding companies between 1986 and 1995.

We conclude this section with a brief description of some features of the empirical analysis we perform in this article. Our analysis builds on the empirical work of Barth et al (2006). However, besides having a much more limited scope than that study, our approach differs from theirs by using transaction-level data across countries, instead of taking essentially a country-level approach. Our study relies on the cross-country surveys on bank regulation and supervision performed by Barth et al. $(2001,2006,2008)$ as its source of data on bank regulations. These surveys consist of hundreds of rules regarding bank regulation and supervision adopted by more than 100 countries around the world. To measure bank regulatory and supervisory policies, we borrow the approach proposed by those same authors 
(Barth et al., 2006, chapter 4), which consists in using broader indices as empirical proxies rather than an "examine-every-rule" approach. They argue that the broader approach is statistically preferred, as many individual rules would render impossible the identification of their independent impact on bank operations. Furthermore, it is also preferred from a theoretical viewpoint, as there are only few broad concepts of bank regulation and supervision. Finally, the broader approach is specifically appropriate for this study, as our focus is to measure how three broad regulatory mechanisms influence some loan contracts features. These mechanisms mirror the Basel II's three pillars framework, although our study is not making an assessment of the specific effectiveness of Basel II. Instead, our empirical approach relies on explanatory variables represented by the indices for Capital Requirements Stringency, Official Supervisory Power and Private Monitoring, suggested by Barth et al. (2006), to represent respectively bank capital regulations, supervisory power and market discipline.

\section{Empirical hypotheses}

We propose the following hypotheses to be tested in our sample. We take the public interest view to regulation when deriving them. Such approach implies that the hypotheses proposed are not necessarily the ones mainly expected by theory. Our purpose is not favouring the public interest view. On the contrary, it is to impose an arbitrary impartial discipline able to avoid driving the conclusions to any direction. We believe the evidence to be obtained is useful as a test of the theoretically well grounded hypotheses. It is also important in shedding a light on the weak or ambiguously theoretically grounded ones.

From a public interest view, the regulations imposed on banks by countries are mechanisms capable to contain risk-taking behaviour of banks and, ultimately, to help assuring banks' soundness, financial stability and economic growth. In a context of bank lending across a set of countries, we propose the following hypotheses to examine whether each of the bank regulations measures is associated with loan priced risk characteristics, represented by spread and maturity:

H1: More stringent capital regulations reduce priced risk characteristics of loan contracts. Hence, they reduce loan spreads and increase loan maturities.

H2: Higher official supervisory power reduces priced risk characteristics of loan contracts. Hence, it reduces loan spreads and increase loan maturities. 
H3: More private monitoring on banks reduces priced risk characteristics of loan contracts. Hence, it reduces loan spreads and increase loan maturities.

Provided that the influence of bank regulations on bank risk-taking behaviour is not a consensual issue, either from a theoretical viewpoint and the empirical evidence available, we consider checking the existence of nonlinear relationships between bank regulations and the risk characteristics of loan contracts.

Furthermore, given the comprehensiveness of our dataset, we are able to extend our analysis by examining complementarities and interactions between both regulatory mechanisms themselves, and other country factors. For such, we rely on enriching the assessment of the previous hypotheses by introducing interaction terms between bank regulations themselves and between these and country factors such as the levels of bank competition, financial development and legal enforcement, as well as considering subsamples across these same country factors.

Similarly to Barth et al (2006), one limitation of our study is to use bank regulations variables that are constructed based on a survey of statutory powers, which does not necessarily reflect how regulations work on the ground. Accordingly, our findings have to be analyzed with caution. In any case, by conducting econometric analyses on a novel sample that mergers country and transaction-level data, we believe we make a contribution to the literature on the evidence of how bank regulations influence lending practices of banks.

\section{Data description}

The main source of our data is the LPC Reuters DealScan database, which provides detailed data on loans made all over the world by banks to large firms. Such loan level information includes many features of loan contracts, such as lender and borrower identities, dates of origination, purpose of loan, deal amounts, number of lenders, lender deal share, spreads, loan maturity, covenants, and borrower sector and ratings. To conduct our crosscountry study on bank regulations, we adopt the loan deal as the unit of analysis. At the same time, we are interested in the behaviour of banks. Therefore, our sample selection consisted in taking, whenever possible, the 15 largest commercial banks or banking holding companies in 
terms of total assets, in 39 of the 49 countries included in the study of La Porta et al. (1998) 7 . Besides establishing a limit in the number of countries included in the study, we believe that such selection allows comparability with other cross-country studies, mainly related to the "law and finance" literature. Then, we collected information on all confirmed loan deals originated by those banks from 1998 to 2006 . Such selection of period is motivated by the availability of bank regulations data, which consist of surveys made by the World Bank in the years 2000, 2003 and 2007 (Barth et al., 2001, 2006, 2008). We assume that country bank regulations reported by those surveys are in place for the following 3-year periods: 1998 to 2000, 2001 to 2003 and 2004 to 2006. Hence, yearly bank regulations variables representing each country's capital requirements stringency, official supervisory power and the level of private monitoring are added to the database. Similarly, other country-level variables are included, namely, the borrower country's sovereign debt rating, the level of legal protection of creditors in borrower country, and proxies for lender country's level of financial development, and borrower country's economic development, economy size, and business cycle. Finally, bank-level characteristics are collected from the Bankscope database, and hand-matched with the loan deal level information. Raw data from DealScan was filtered to allow only confirmed loans, and to exclude loans made to firms in the financial and in the public sectors (first digit of SIC code equal to 6 or 9). These loans are dropped because the risks of firms in these sectors are argued to be very different from other firms, as they are likely to be government owned or government protected monopolies (Qian and Strahan, 2007). Considering that some banks have no loans reported by DealScan, and that in fact less than 15 banks were included for some countries, we ended up with a sample of 46,453 loans originated by 278 banks around 39 countries, to borrowers distributed in 83 countries, during the period from 1998 and 2006. What follows is a description of the variables used in the analyses.

\section{Dependent Variables}

The following variables represent the loan contract characteristics selected to be examined if they are affected by bank regulations, after controlling by other country-level, loan-level, lender-specific and borrower-specific characteristics:

\footnotetext{
${ }^{7}$ New Zealand was excluded because most banks there are owned by Australian banks. Scarcity of data motivated the exclusion of Colombia, Ecuador, Kenya, Nigeria, Peru, Sri Lanka, Turkey, Uruguay and Zimbabwe.
} 
- Spread: this variable corresponds to the "All-in Spread Drawn" information available for each deal in the DealScan database It consists of the base points in excess of the interbank market rate that is asked by lenders to borrowers in a deal. It also incorporates any charged fees associated to the loan. The Spread variable is assumed to reflect the risk that a lender prices to the borrower in a specific loan contract.

- Log of Maturity: it is the logarithm of the maturity of a loan, expressed in number of months. As well as the Spread variable, Maturity is supposed to be a contract feature that reflects the risk priced by the lender to the borrower in a loan.

\section{Explanatory Variables}

When studying the influence of bank regulations on loan contracts characteristics, we include four different sets of explanatory variables: country-level, lender-specific, borrowerspecific, and loan-level. The first set includes country-level variables reflecting: (1) some supply-side factors that may affect the availability of funds and the loan contracts characteristics, i.e., the conditions in which lenders want to extend loans to borrowers. The variables that represent the focus of this study, namely, the country-level bank regulations, are included in this set, as well as institutional variables at the lender country level such as financial development, legal enforcement and bank competition; (2) demand-side factors, such as the level of economic development, the business cycle, and sovereign credit ratings in borrowers' countries. The second set consists of lender-specific characteristics, such as its size and leverage, which represent supply-side factors at the loan deal level, and likely influence loan contracts features. The third set of explanatory variables refers to borrowerspecific characteristics representing both demand-side and credit risk factors, essential to determine loan contracts characteristics. The fourth set of variables includes characteristics of the loans, other than those used as dependent variables, which also relate to demand-side and credit risk factors determining loan contract features. Additionally, year dummies are included as explanatory variables. Appendix I provides a detailed description of all explanatory variables, grouped in the described sets.

\section{Descriptive Statistics}

Basic descriptive statistics of the main variables is shown in Table 1.

\section{Insert Table 1 about here}


Table 1 shows that the average spread of the deals is 188.8 basis points over LIBOR, while average maturity is 55.3 months ( 3.7 on a log scale). The mean deal amount is at 396 millions of US dollars (the mean of the logarithm of deal amount is 18.8), with a high percentage of loans $(63 \%)$ made to borrowers located in the same country as the lender. Regarding the variables describing banks' characteristics, the average annual total assets of a bank are 204 billions of US dollars (the mean of the logarithm of bank total assets over the whole sample of deals is 20), while mean leverage is at $94 \%$. The variables on regulatory measures indicate that Capital stringency has a mean value of 6.4 in a range between 2 and 10, Official supervisory power has a mean value of 11.1, ranging from 4 to 14, and Private Monitoring has a mean value of 8.8 and ranges from 5 to 11 . On the borrowers' side, Table 1 indicates that La Porta et al (1998).'s Creditor Rights index has a mean value of 1.5, ranging from 0 to 4 and that the Sovereign Rating Score of credit risk has a mean value of 2.4, ranging from 1 to 24. Finally, the set of macroeconomic variables related to a borrower country's GDP indicates a wide dispersion of values among the borrowers' countries.

In general, our heterogeneous sample of countries offers high enough variability across the different variables for conducting an econometric analysis. Table 2 presents the mean values of bank regulations and other institutional country level variables, for each lender country in our sample, while Table 3 shows country mean values of variables describing macroeconomic and creditors' rights conditions of borrower countries.

\section{Insert Tables 2 and 3 about here}

Initial evidence of the correlation between variables is shown in Table 4. Remarkably, the variable for Capital requirements stringency shows a slightly negative correlation with the loan Spread, which suggests that, when forced to improve their level of capitalization, banks become sound and can afford to demand lower interest rates to borrowing firms. Concerning the other variables of bank regulations (Official supervisory power and Private Monitoring), they are positively correlated with Spread, and negatively correlated with loan Maturity. Hence, contrary to the Capital regulation measure, banks seem to transfer the pressure they suffer from Official supervision and Private Monitoring to their loans by increasing loan interest rates and shortening loan maturities. It is noticeable the positive correlations between bank regulations themselves, especially Capital with Official (26\%) and Official with Private Monitoring (43\%). In principle, these correlations seem to support the bank regulatory policy approach of reinforcing mechanisms designed to influence bank behaviour. Regarding other 
country level controls, the level of Financial Development of the lender country has respectively small negative and positive correlations with Spread and Maturity, suggesting that the higher the level of Financial Development, the less risky are loan contracts. Turning to borrower country-specific controls, we notice that the Creditor Rights variable is weakly negatively correlated with Spread and positively correlated with Maturity. It might indicate that protecting creditors is beneficial in terms of reduction of risk taking in lending. Finally, given the extremely high negative correlation between borrower country Sovereign Credit Score and Log of GDP per capita (-88\%), we decided to not include the last variable in the regressions to avoid problems of multicollinearity.

\section{Insert Table 4 about here}

\section{Methodology and Results}

Our sample is structured in individual observations of loan deals originated across a 9-year period. One or more banks participate in each deal, and each bank participates in more than one deal, in each year ${ }^{8}$. Therefore, the loan deal is the level of analysis that allows the best use of the information available, regarding each individual loan characteristics ${ }^{9}$. Each loan deal is a unique event that produces the characteristics of a loan contract and for such it is treated as a separate individual. This invalidates any possibility of using fixed effects techniques across deals.

We concluded that OLS regression is the method of analysis more suitable to our sample. We pooled all individual observations distributed across the 1998-2006 period to undertake single regressions. Year dummies were included in all regressions to take into account possible cyclical and time specific factors not captured by the explanatory variables. It is assumed that observations are independent across banks, but not necessarily independent within the same bank. Hence, robust standard errors clustered by banks are reported in all regressions.

We recognize that many loan characteristics are jointly determined, which raises a concern for possible endogeneity of regressors if those characteristics are used as explanatory variables. We minimize this issue by simply restricting the loan-specific explanatory variables

\footnotetext{
8 Although the same loan may be extended by many banks (e.g., a syndicated loan), there is no loan replication in the sample, i.e., a loan deal is included only once.

${ }^{9}$ An alternative analysis could be panel regressions on bank-level data across the 1998-2006 period. That would require the aggregation of information about the deals in which a bank participates in each year. Such aggregation, however, would imply losing of information.
} 
to the deal amount and dummies for most common deal purposes and deal types (see Appendix 1). We do not use loan Spread or Maturity as independent variables, i.e., each one appears only once in each regression, always as a dependent variable. Otherwise, more sophisticated techniques would be required, instead of plain OLS regressions. We also believe that the problem of omitted variables as a source of endogeneity is minimized with the use of a comprehensive set of regressors grouped in country-level, lender-specific, borrowerspecific, and loan-level explanatory variables representing supply and demand side factors affecting loan contract features. Problems of reverse causality are not a concern, as the majority of our explanatory variables are at the country-level, whereas the dependent variables are at the transaction level.

The cross-country characteristic of our sample reveals another source of concern, which is the high dispersion in the number of observations per country. High economic developed lender countries have in general much more observations than low developed ones. For example, banks in the U.S. participate in $39 \%$ of the loans. A problem exists if these banks drive the overall results by putting more weight on the country explanatory variables. To tackle this problem, we performed a robustness check by running all the regressions excluding U.S. lenders. The (unreported) results are not substantially changed, and validate the conclusions of this paper.

To test hypotheses $H 1$ to $H 3$ proposed in Section II, we ran OLS regressions of loan Spread and Maturity on bank regulations variables, while controlling for the country, lender, borrower and loan specific factors described in Section II. The regressions are for the whole period (1998-2006), and encompass the three Barth et al. (2001, 2006, 2008) surveys subperiods of 1998-2000, 2001-2003 and 2004-2006. Results are in Table 5.

\section{Insert Table 5 about here}

Regression $R 1$ of Table 5 shows that Capital requirements stringency is negatively related to loan Spread. However, the inclusion of a quadratic term in regression $R 2$ of Table 5 reveals an inverse U-shaped relationship between Capital requirements and Spread, with the maximum Spread occurring at a Capital level of 4.9, which is in the $10 \%$-quantile of the sample. It means that countries with low or high levels of Capital stringency are the ones that experience lower Spread, whereas intermediate levels of Capital are associated with higher loan Spread. 
The results concerning the effect of Capital on loan Maturity are very similar. Regression $R 4$ in Table 5 shows a U-shaped relationship between Capital requirements and Maturity, with minimum Maturity at a Capital level of 4.2, which is also in the $10 \%$-quantile of the sample. It means that loans in countries with low or high levels of Capital stringency experience longer maturities.

Respectively for loan Spread and Maturity, the inverse and direct U-shaped relationships with Capital stringency found in Regressions $R 2$ and $R 4$ in Table 5, reveal a consistency between loan spread and maturity as risk measures. Theoretically, it may be supported by the so-called "signalling hypothesis" (Dennis et al., 2000), by which a longer maturity is a signal of good credit quality, which in turn translates to a lower loan rate.

Summing up, these results show an inverse U-shaped relationship between loan risk characteristics and Capital requirements stringency: low priced risk terms of loan contracts, represented by low Spread and long Maturity, are associated with either low or high Capital requirements stringency, while loan contracts with higher risk characteristics prevail when the stringency of Capital regulations is moderate. Although consistent, these results do not unambiguously support hypothesis $H 1$. For medium to high levels of Capital stringency, risk measures behave as proposed by the public interest view of regulation implicit in $H 1$, i.e., risk measures decrease as Capital stringency grows. Nevertheless, the low risk reflected in loan contracts in countries with low Capital stringency and its increasing behaviour up to medium levels of Capital stringency threatens this view, although it is well grounded in some theoretical models, notably the ones that emphasize the role of banks as monitors for moral hazard risks. For instance, Besanko and Kanatas (1996) argue that the issuance of equity to meet capital requirements decrease loan monitoring incentives as a result of the dilution of insiders' shareholders stake. One of the consequences is higher loan loss probabilities, which reflect in higher spreads. Another interpretation for the increasing relationship between risk measures and capital stringency for low to medium levels of the latter is that banks react to moderate capital regulations stringency by increasing spreads and shortening maturities, without changing their credit policies in the direction of strengthening loan screening and monitoring, which in turn would result in less risky loan contracts. Under this interpretation, only when capital regulations stringency is sufficiently large, banks strengthen their credit policies. A third possible explanation for the observation of riskier loan contracts at moderate stringency of capital regulations may be that incentives to risk-shifting are greater at higher probabilities of default deriving from moderate levels of capital stringency. By contrast, at 
high stringency of capital regulations, probabilities of default are lower, resulting in lower incentives to risk-shifting and less risky loan contracts.

Regarding the other regulatory measures, we do not find any relationships between loan Spread and Official supervisory power or Private Monitoring. However, Official supervisory power has a significant negative impact on loan Maturity. Together, the evidence found is against hypothesis $H 2$, while hypothesis $H 3$ is not supported. Concerning the role of bank supervision, it suggests that the private interest view prevails, in the sense that more empowered supervisors are associated to riskier bank lending, resulting in shorter maturities of loan contracts. Another interpretation may be that official supervision induces more conservative behaviour on the part of banks, which mitigate risk through the reduction of loan maturity. More conclusions on the effects of the three bank regulatory indices on loan contracts characteristics are given later in this section, when interactions between them are introduced.

Concerning control variables, borrowers with poor senior debt Rating obtain funds through loans with higher spreads, according to regressions $R 1$ and $R 2$ in Table 5. These expected results for Spread contrast with the opposed ones obtained for loan Maturity. However, consistently with Diamond's (1991) model, borrowers may use short loan maturity as a way to improve their ratings. Note that we found lower spreads for better rated firms, but also shorter maturities, as lenders may want to update such favourable credit conditions to borrowers in a frequent basis, particularly larger banks, that have less soft information (negative coefficient for Lender Assets in regression $R 3$ of Table 5). The coefficient for Log of Deal Amount suggests that larger loan amounts are associated with loan contracts in better terms, which are captured by lower spreads and longer loan maturities. In addition, there is evidence that lower spreads are charged in loans extended to borrowers located in the same country as the lender, which suggests that problems of information asymmetry influence the risk terms of loan contracts. Concerning country-specific variables, the higher (worse) the Sovereign Credit Risk, the higher the loan contract risk measures (higher the Spread and shorter the Maturity), which is an expected result. Surprisingly, the variable for the economy size of borrower country, given by $\log (G D P)$, has a positive effect on risk measures. On the other hand, variable GDP Growth reduces spreads and increases maturities, which supports an expected relationship between relaxed risk pricing and growth cycles. The lender country level of Financial Development does not enter significantly to explain neither loan Spread nor Maturity. However, further analyses are offered for this variable later. 
Next, we seek to examine how interactions between bank regulations may affect loan spreads and maturity. We included interaction terms in the previous regressions and reported only the significant results in Table 6. From regression $R 3$ in Table 6 , we found again that Official supervisory power linearly decreases loan Maturity, but it interacts with Capital stringency to positively influence loan Maturity. Given the quadratic relationship between Capital and Maturity, we conclude that for low levels of Capital, where Maturity decreases with Capital, the opposite (positive) sign of the interaction term (Capital*Official) means that Capital decreases Maturity more for low levels of Official. In other words, it suggests that in countries where supervisory power is high, more stringent capital regulations are less prone to increase risk by decreasing maturity, which means these bank regulations work as substitutes. For higher levels of Capital, where Maturity increases with Capital, Official reinforces Capital to increase loan Maturity. Summing up, for low levels of capital stringency, official supervisory power counteracts with capital regulation to lower the decrease in loan maturity, while for high levels of capital stringency, the mechanisms reinforce each other to increase maturity.

The evidence on interactions between capital stringency and private monitoring to influence risk comes both from spread and maturity measures. Regressions $R 1$ and $R 2$ in Table 6 convey the same message: for low levels of capital stringency, where Spread increases and Maturity decreases with Capital, Capital increases risk measures more for low levels of Private Monitoring; for high levels of capital stringency, Private Monitoring helps Capital to reduce loan risk characteristics (decreases spread and increases maturity).

We conclude that the evidence regarding interactions between bank regulations is mixed. On the one hand, Capital and Official complement each other to reflect less risky loan contracts (through increasing loan Maturity) only when the level of Capital stringency is high. Similarly, Capital and Private Monitoring complement each other to reduce loan contract risk measures (through decreasing Spread and increasing Maturity) only when Capital stringency is high. On the other hand, Official and Private Monitoring behave as substitutes to Capital in reducing loan contracts risk measures when a country's level of Capital stringency is low.

\section{Insert Table 6 about here}

Results in Tables 7 to 9 provide evidence on interactions between regulations and other country-level factors. We split the sample in sub-samples of low and high Rule of Law, 
lender country Financial Development, and Competition (measured by lender country's logarithm of number of banks), according to their medians across lender countries. Concerning the influence of Capital stringency variable on loan contracts risk characteristics, the results show a sharp contrast between sub-samples of low and high values of those lender country variables. Regressions in second, fourth and sixth columns of both Tables 7 and 8 point that capital stringency decreases priced risk loan characteristics (i.e., decreases Spread and increases Maturity) especially in lender countries with high levels of legal enforcement (measured by Rule of Law), financial development and competition. These findings are very reasonable, as they highlight the importance of a country's levels of financial development, enforcement of law, and banking industry competition, as mechanisms that enable the effectiveness of capital regulations in reducing loan risk terms.

From the regressions in third column of Table 7, and first and third columns of Table 8 , we conclude that private monitoring increases risk characteristics of loan contracts in countries with poor developed legal and financial systems. Such evidence on private monitoring supports the public interest view of regulation, according to which it is not recommended to rely on the external monitoring of markets to contain bank risk taking when financial development is not high enough.

\section{Insert Tables 7 and 8 about here}

We extend our analysis of the influence of institutional factors at the lender countrylevel by including interaction terms between them and bank regulations variables in the regressions. There were no significant results for loan Spread, while loan Maturity appears affected by these interactions. It suggests that maybe loan Spread has lower sensibility to this kind of interactions, when compared to loan Maturity. Alternatively, it is the case that loan Spread is well explained by the basic determinants of Tables 5 and 6, with no room for interactions between bank regulations and other lender country factors. Table 9 reports the significant results for loan Maturity. In principle, Rule of Law is not significant to help explaining loan Maturity (results unreported). However, regression R1 in Table 9 shows that Rule of Law interacts with Capital regulations stringency to influence loan Maturity. Similarly to results in Table 5, we found a direct U-shaped relationship between Capital and Maturity. The interaction term between Capital and Rule of Law is positive. Accordingly, at low levels of Capital stringency, for which Maturity decreases with Capital, the interaction 
produces an opposite effect, which means that Rule of Law interacts with Capital to alleviate the decrease in Maturity. For high levels of Capital stringency, at which Maturity increases with Capital, the interaction is in the same direction, which means that increasing both Rule of Law and Capital has a stronger impact in increasing loan Maturity. Therefore, Rule of Law has the unambiguous marginal effect of risk reduction, through its combination with Capital stringency to increase the Maturity of loan contracts. Figure 1 illustrates, for three different levels of Rule of Law, the joint effect of Capital and Rule of Law on loan Maturity ${ }^{10}$ according to regression $R 2$. It is clear from Figure 1 that stricter capital regulations are more effective in increasing the maturity of loan contracts when the country's legal system is more enforceable. Moreover, more stringent capital regulations in countries with poor rule of law experience a stronger decreasing impact on loan maturities, when compared to countries with higher rule of law. Together, the evidence from Tables 7,8 and 9 shows that capital regulations are more effective in reducing the risk of lending when legal systems are more developed.

Competition interacts with Capital stringency to positively influence loan Maturity, according to regression $R 2$ in Table 9. At low levels of Capital, where Maturity decreases with Capital, the interaction term has the opposite effect on Maturity. Similarly to Rule of Law, Competition has an unambiguous marginal effect of decreasing risk of loan contracts, through its joint impact, with Capital stringency, of increasing loan Maturity. . Figure 2 illustrates, for three different levels of Competition, the joint effect of Capital and Competition on loan Maturity found in regression $R 4$ of Table 9. Together with the previous evidence of Tables 7 and 8, this finding supports the idea that more stringent capital regulations are more effective in reducing risk characteristics of loan contracts when bank industries are more competitive. Despite the negative coefficient of Competition alone, it is clear from Figure 2 that the positive interaction between it and Capital offsets that negative influence on Maturity when Competition is above median and Capital stringency level is greater than 4 .

Our last piece of evidence concerns the interaction of Private Monitoring with Rule of Law and Competition. Regressions $R 3$ and $R 4$ in Table 9 show positive coefficients for the interaction terms between these variables. Given that Private Monitoring has a negative coefficient, the effect of interactions is to counterbalance the decreasing impact of Private Monitoring on loan Maturity. Precisely, Private Monitoring linearly reduces loan Maturity,

\footnotetext{
${ }^{10}$ The lines plotted in Figure 1 correspond to the joint effect of Capital and Rule of Law on Maturity. The dependent variable in regression $R 2$ in Table 9 is the logarithm of loan maturity. Hence, the function plotted is a factor that, after multiplied by other factor including the remaining explanatory variables, equals loan maturity.
} 
but this effect is more important when the levels of either Rule of Law or Competition are low. Figures 3 and 4 illustrate the models of, respectively, regressions $R 3$ and $R 4$. Due to negative coefficients of both Private Monitoring and Rule of Law, the combination of low Rule of Law and Private Monitoring up to a level of 10 produces the longest maturities. However, Figure 3 shows that the interaction term is able to make increasing the relationship between Private Monitoring and loan Maturity when Rule of Law is above its mean. On the other hand, due to a lower negative impact of Competition alone on Maturity (R4), when compared to the impact of Rule of Law alone (R3), only the combination of low Private Monitoring and low Competition produces the longest maturities. Figure 4 shows that, for levels of Competition above its median, the positive effect of the interaction on loan Maturity more than offsets the negative individual impacts of both Private Monitoring and Competition on Maturity, resulting in an increasing relationship between Private Monitoring and loan Maturity. The evidence adds to that obtained in Table 6 , and reinforces that, although external private monitoring on banks solely increases the risk characteristics of loan contracts, its interaction with either Capital stringency, Rule of Law, or Competition, highlights its importance as a complementary mechanism in the reduction of lending risk.

Regression $R 5$ in Table 9 shows that all previous interaction effects treated in regressions $R 1$ to $R 4$ are still present when they are simultaneously included in the same model. Finally, we conclude for the evidence of a complementary role of both bank competition and legal enforcement to bank regulations in achieving the reduction of priced risk characteristics of loan contracts.

\section{Insert Table 9 about here}

\section{Insert Figures 1 to 4 about here}

\section{Conclusions}

In this paper we empirically examined the effect that three broad bank regulations implemented by countries exert on banks' credit policies: the level of stringency of capital restrictions imposed to banks, the degree of the power that the official supervisor authority 
has to oversee and intervene in the functioning of banks, and the degree to which banks are exposed to external private monitoring, apart from official regulatory oversight.

The results indicate that priced risk terms of loan contracts have an inverse U-shaped relationship with capital regulations stringency. Precisely, we found evidence of loan contracts with lower spreads and longer maturities when the stringency of capital regulations is either low or high, while higher spreads and shorter maturities are associated to moderate levels of capital stringency. The decreasing behaviour of loan contracts' risk measures from moderate to high levels of capital stringency favours the view that strengthening capital regulations contains bank risk taking. However, the increasing behaviour of risk measures from low to medium levels of capital stringency opposes that view and supports the argument of a reduction in loan monitoring incentives by banks as a consequence of toughening capital requirements. However, it may be the case that higher risk measures in this region is simply the result of shifting the pressure of slightly stricter capital regulations to loan price terms, rather than the banks' reaction to capital toughening in the form of relaxing credit policies, which would be the case only if capital regulations become significantly stringent. Regarding the role of official supervision, we found that more empowered supervisors contribute to riskier bank lending, through the shortening of loan contracts' maturities. Interestingly, there is evidence of interactions between bank regulations influencing loan contracts risk terms: both official supervisory power and private monitoring behave either as substitutes or complements to capital stringency to reduce loan contracts risk measures, depending whether capital stringency is respectively low or high. Together, this evidence reveals that, at high levels of capital regulations stringency, loan contracts tend to experience less riskas a consequence of both the superior financial soundness of better-capitalized banks and the complementary roles of supervision and market discipline in containing bank risk-taking.

This study provides a valuable piece of evidence on the interactions between bank regulations and other institutional country level factors when influencing bank lending. We found that a country's levels of financial development, enforcement of law, and competition in the banking industry, are mechanisms that enable the effectiveness of capital regulations in reducing loan contracts risk terms. Finally, we found that although external private monitoring on banks alone increases the risk characteristics of loan contracts, its interaction with both capital regulations stringency and banking competition highlights its importance as a complementary mechanism in the reduction of the risk of lending.

The results suggest more complex interactions between bank regulations to influence risk taking behaviour than simply playing complementary roles, as advocated by proponents 
of reinforcing pillars of Basel II. Loan contracts in countries where capital regulations are more relaxed experience longer maturities, and this is especially true if official supervisory power is also low. Increasing capital stringency up to a moderate level shortens maturity but this effect is counterbalanced if official supervisory power is high, which suggests that official supervision substitutes capital in keeping loan maturities long.

This paper opens avenues for future research. The analysis presented is crosssectional, given that we have only three waves of data concerning the regulatory indices used. If more data become available in the form of another survey of bank regulation and supervision, these can be incorporated to enhance our estimation techniques. A new survey would open the possibility for conducting a longitudinal analysis of how variation in regulatory measures produce changes in the credit policy followed by each individual bank, e.g., through fixed effects estimation. Such longitudinal approach will help tackling endogeneity issues of reverse causality related to the changes in regulation triggered by certain condition in the credit market and issues related to cost adjustments. Finally, issues of simultaneous versus sequential implementation of both capital requirements and supervision regulations will be properly addressed in a longitudinal study. 


\section{REFERENCES}

Allen, F., and Gale, D. (2000). Comparing Financial Systems. Cambridge, MA: MIT Press.

Ashcraft, A. (2001). Do tougher bank capital requirements matter? New evidence from the eighties. Manuscript, Federal Reserve Bank of New York.

Barrios, V., Blanco, J. (2003). The effectiveness of bank capital adequacy regulation: A theoretical and empirical approach. Journal of Banking and Finance 27, pp. 19351958.

Beatty, A., Gron, A. (2001). Capital, Portfolio, and Growth: Bank behaviour under risk-based capital requirements. Journal of Financial Services Research 20, pp 5-31.

Barth, J. (1991). The Great Savings and Loan Debacle (Washingtion, DC: The AEI Press).

Barth, J., Caprio, G., Levine, R. (2001). Bank Regulation and Supervision: A New Database. in Litan R., Herring R., eds., Brookings-Wharton Papers on Financial Services, 2001 .

(2004). Bank regulation and supervision: What works best? Journal of Financial Intermediation 13, pp. 205-248.

(2006). Rethinking Bank Regulation: Till Angels Govern. (New York: Cambridge University Press).

(2008). Bank Regulations Are Changing: For Better or Worse? World Bank Policy Research Working Paper Series No. 4646

Basel Committee on Bank Supervision (2004). International Convergence of Capital Measurement and Capital Standards: A Revised Framework, mimeo, Bank for International Settlements, http:ww.bis.org/bcbs/index.htm

Beck, T., Demirgüç-Kunt, A., Levine, R. (2000). A New Database on Financial Development and Structure. World Bank Economic Review, no. 14, pp. 597-605.

Berger, A., Davies, S., Flannery, M. (2000). Comparing market and supervisory assessments of bank performance: Who knows what when? Journal of Money, Credit, and Banking 32, pp. 641-667.

Berger, A., Udell, G. (1994). Did risk-based capital allocate bank credit and cause a credit crunch in the United States? Journal of Money, Credit and Banking 26, pp. 585-628.

Besanko, D., Kanatas, G. (1996). The Regulation of Bank Capital: Do Capital Standards Promote Bank Safety? Journal of Financial Intermediation 5, pp. 160-183.

Bernanke, B., Gertler, M. (1995). Inside the Black Box: The Credit Channel for Monetary Policy Transmission. Journal of Economic Perspectives 9 (4), pp. 27-48. 
Boot, A., Marinc, M. (2006). Competition and entry in banking: Implications for Stability and Capital Regulation. Tinbergen Institute Discussion Paper TI 2006-015/2.

Boot,. A, Thakor (2001). The many faces of information disclosure. Review of Financial Studies 14, pp. 1021-1057.

Brinkmann, E., Horvitz, P. (1995). Risk-based capital standards and the credit crunch. Journal of Money, Credit, and Banking 27, pp. 848-863.

Calem, P., Rob, R. (1999). The impact of capital-based regulation on bank risk-taking. Journal of Financial Intermediation 8, pp. 317-352.

Campbell, T., Chan, Y., Marino, A. (1992). An incentive-based theory of bank regulation. Journal of Financial Intermediation 2, pp. 255-276.

Caprio, G., Honohan, P. (2004). Can the Unsophisticated Market Provide Discipline?, in Borio, C., Hunter, W., Kaufman, G., Tsatsaronis, K., eds., Market Discipline Across Countries and Industries, pp. 349-362. (Cambridge, MA: The MIT Press).

Chan, Y., Greenbaum, S., Thakor, A. (1992). Is Fairly Priced Deposit Insurance Possible? Journal of Finance 47, pp. 227-245.

Chen, Y., Hasan, I. (2006). The transparency of the banking system and the efficiency of information-based bank runs. Journal of Financial Intermediation 15, pp. 306-331.

Chiuri, M., Ferri, G., Majnoni, G. (2002). The macroeconomic impact of bank capital requirements in emerging economies: past evidence to assess the future. Journal of Banking and Finance 26, pp. 881-904.

Decamps, J., Rochet, J., Roger, B. (2004). The three pillars of Basel II: Optimizing the mix. Journal of Financial Intermediation 13, pp. 132-155.

Dell'Aricia, G., Marquez, R. (2006). Competition among regulators and credit market integration. Journal of Financial Economics 79, pp. 401-430.

Dennis, S., Nandy, D., Sharpe, I. (2000). The Determinants of Contract Terms in Bank Revolving Credit Agreements. Journal of Financial and Quantitative Analysis 35(1), pp. 87-110.

DeYoung, R., Flannery, M., Lang, W., Sorescu, S. (2001). The information content of bank exam ratings and subordinated debt prices. Journal of Money, Credit, and Banking 33, pp. $900-925$.

Diamond, D. (1991). Monitoring and Reputation: The Choice Between Bank Loans and Directly Placed Debt. Journal of Political Economy 99, pp. 689-721.

Diamond, D., Rajan, R. (2000). A theory of bank capital. Journal of Finance 55, pp. 24312465. 
(2001). A Liquidity risk, liquidity creation, and financial fragility: A theory of banking. Journal of Political Economy 109, pp. 287-327.

Distinguin, I., Rous, P., Tarazi, A. (2006). Market discipline and the use of stock market data to predict bank financial distress. Journal of Financial Services Research 30, pp.151176.

Dowd, K. (2000). Bank capital adequacy versus deposit insurance. Journal of Financial Services Research 17, pp. 7-15.

Estrella, A. (2004). Bank capital and risk: Is voluntary disclosure enough? Journal of Financial Services Research 26, pp. 145-160.

Evanoff, D., Wall, L. (2001). Sub-debt yield spreads as bank risks measures. Journal of Financial Services Research 20, pp. 121-145.

Flannery, M. (2001). The faces of "market discipline". Journal of Financial Services Researh 20, pp. 107-119.

(1998). Using market information in prudential supervision: A review of the U. S. empirical evidence. Journal of Money, Credit, and Banking 30, pp. 273-305.

Flannery, M., Rangan, K. (2004). What caused the bank capital build-up of the 1990s? FDIC Center for Financial Research Working Paper No. 2004-03.

Flannery, M., Sorescu, S. (1996). Evidence of bank market discipline in subordinated debenture yields: 1983-1991. Journal of Finance 51, pp. 1347-1377.

Freixas, X., Rochet, J. (1995). Fair Pricing of Deposit Insurance. Is it Possible? Yes. Is it Desirable? No. Mimeo, Universitat Pompeu Fabra, Barcelona.

Furfine, C. (2001). Bank portfolio allocation: The impact of capital requirements, regulatory monitoring, and economic conditions. Journal of Financial Services Research 20, pp. 33-56.

Furlong, F. (1988). Changes in bank risk-taking. Federal Reserve Bank of San Francisco Economics Review, pp. 45-56.

(1992). Capital regulation and bank lending. Federal Reserve Bank of San Francisco Economics Review, pp. 23-33.

Hamalainen, P., Hall, M., Howcroft, B. (2003). Market discipline: A theoretical framework for regulatory policy development. In Kaufman, G., ed., Market Discipline in Banking: Theory and Evidence. (Elsevier: Amsterdam), pp. 57-95.

Hart, O., Jaffe, D. (1974). On the Application of Portfolio Theory to Depository Financial Intermediaries. Review of Financial Studies 41, pp. 129-147. 
Haubrich, J., Wachtel, P. (1993). Capital requirements and shifts in commercial bank portfolios. Federal Reserve Bank of Cleveland Economic Review 29, (Quarter 1), pp. $1-15$.

Hendricks, D., Hirtle, B. (1997). Bank capital requirements for market risk: The internal models approach. Federal Reserve Bank of New York Economic Policy Review.

Herring, R. (2004). How Can the Invisible Hand Strengthen Prudential Supervision? and How Can Prudential Supervision Strengthen the Invisible Hand?, in Borio, C., Hunter, W., Kaufman, G., Tsatsaronis, K., eds., Market Discipline Across Countries and Industries, pp. 349-362. (Cambridge, MA: The MIT Press).

Holthausen, C., Rønde, T. (2005). Cooperation in international banking supervision. Manuscript, European Central Bank.

Jackson, P., Furfine, C., Groeneveld, H., Hancock, D., Jones, D., Perraudin, W., Radecki, L., Yoneyama, M. (1999). Capital requirements and bank behaviour: The impact of the Basel accord. Basel Committee on Banking Supervision Working Paper No. 1.

Kane, E. (1989). The S\&L Insurance Mess: How Did It Happen? (Washington, DC: Urban Institute Press).

(1997). Ethical Foundations of Financial Regulation. National Bureau of Economic Research Working Paper 6020.

(2002). Using Deferred Compensation to Strengthen the Ethics of Financial Regulation. Journal of Banking and Finance 26, pp. 1919-1933.

(2004). Financial Regulation and Bank Safety Nets: An International Comparison, mimeo, Boston College.

Kaufmann, D., Kraay, A., Mastruzzi, M. (2008). Governance Matters VII: Aggregate and Individual Governance Indicators, 1996-2007. World Bank Policy Research Working Paper No. 4654.

Kocherlakota, N., Shim, I. (2005). Forbearance and prompt corrective action. BIS Working Paper No. 177.

Kopecky, K., VanHoose. D. (2006). Capital regulation, heterogeneous monitoring costs, and aggregate loan quality. Journal of Banking and Finance 30 (8), pp. 2235-2255.

La Porta, R., Lopez-de-Silanes, F., Shleifer, A., Vishny, R. (1998). Law and Finance. Journal of Political Economy, 106, pp. 1113-1155.

Levine, R. (2006). Finance and Growth: Theory and Evidence. Handbook of Economic Growth, Eds: Philippe Aghion and Steven Durlauf. (The Netherlands: Elsevier Science). 
Llewellyn, D., Mayes, D. (2003). The role of market discipline in handling problem banks. In Kaufman, G., ed., Market Discipline in Banking: Theory and Evidence. (Elsevier: Amsterdam), pp. 183-210.

Lown, C., Peristiani, S. (1996). The behaviour of consumer loan rates during the 1990 credit slowdown. Journal of Banking and Finance 20, pp. 1673-1694.

Marini, F. (2003). Bank insolvency, deposit insurance, and capital adequacy. Journal of Financial Services Research 24, 67-78.

Milne, A. (2002). Bank capital regulation as an incentive mechanism: Implications for portfolio choice. Journal of Banking and Finance 26, pp. 1-23.

Morgan, D. (2002). Rating banks: Risk and uncertainty in an opaque industry. American Economic Review 82, pp. 874-888.

Morgan, D., Stiroh, K. (2001). Market discipline of banks: The asset test. Journal of Financial Services Research 20, pp. 195-208.

Peek, J., Rosengren, E. (1995a). The capital crunch: Neither a borrower nor a lender be. Journal of Money, Credit, and Banking 27, pp. 625-638.

(1995b). Bank regulation and the credit crunch. Journal of Banking and Finance 19, pp. 679-692.

Pyle, D. (1971). On the Theory of Financial Intermediation. Journal of Finance 26, pp. 737 747.

Qian, J., Strahan, P. E. (2007). How Laws and Institutions Shape Financial Contracts: The Case of Bank Loans. Journal of Finance 62 (6), pp. 2803-2834.

Rochet, J. (2003). Rebalancing the 3 Pillars of Basel 2, mimeo, paper prepared for Columbia University - N.Y. Federal Reserve Bank Conference, Beyond Pillar Three in International Bank Regulation.

Santos, J. (1999). Bank capital and equity investment regulations. Journal of Banking and Finance 23, pp. 1095-1120.

(2001). Bank capital regulation in contemporary banking theory: A review of the literature. Financial Markets, Institutions, and Instruments 10, pp. 41-84.

SFRC - Shadow Financial Regulatory Committee (1999). The Basel's Committee's New Capital Adequacy Framework, Statement No. 156. September 27.

(2001). Statement on the Basel Committee's revised capital accord proposal. Statement No. 169, February 26.

Sheldon, G. (1996). Capital adequacy rules and the risk-seeking behaviour of banks: A firmlevel analysis. Swiss Journal of Economic and Statistics 132, pp. 709-734. 
Shim, I. (2006). Dynamic prudential regulation: Is prompt corrective action optimal? BIS Working Paper No. 206, May.

Sleet, C., Smith, B. (2000). Deposit insurance and lender-of-last-resort functions. Journal of Money, Credit and Banking 32, pp. 518-575.

VanHoose, D. (2006). Bank behaviour under capital regulation: What does the academic literature tell us? Networks Financial Institute Working Paper 2006-WP-04.

(2007). Market discipline and supervisory discretion in banking: Reinforcing or conflicting Pillars of Basel II? Networks Financial Institute Working Paper 2007-WP06 .

Verrecchia, R. (1983). Discretionary disclosure. Journal of Accounting and Economics 5, pp. 179-194.

Wagster, J.(1999). The Basel accord of 1998 and the international credit crunch of 19891992. Journal of Financial Services Research 15, pp. 123-143.

White, L. (1991). The S\&L Debacle: Public Policy Lessons for Bank and Thrift Regulation (Oxford, UK: Oxford University Press). 


\section{Appendix 1 - Description of Explanatory Variables}

\begin{tabular}{|c|c|c|}
\hline Variable & Description & Source \\
\hline \multicolumn{3}{|l|}{ Lender country specific } \\
\hline Capital Stringency & $\begin{array}{l}\text { It is the Capital Requirements Stringency Index of Barth et al. (2006). It measures the level of } \\
\text { stringency of capital restrictions imposed to banks, such as eligible funds for entering in the } \\
\text { banking industry, and the use of risk based approaches by central banks when defining capital } \\
\text { ratio requirements. Constructed for three periods (1998-2000, 2001-2003 and 2004-2006), using } \\
\text { data from the surveys on bank regulation and supervision conducted by the World Bank. In our data, } \\
\text { it ranges from } 2 \text { to its maximum possible value of 10, with higher values representing stricter } \\
\text { capital regulations. }\end{array}$ & $\begin{array}{l}\text { Barth et al. (2001, } \\
\text { 2006, 2008). }\end{array}$ \\
\hline Official Supervisory Power & $\begin{array}{l}\text { It is the Official Supervisory Power Index of Barth et al. (2006). It represents the degree of the } \\
\text { power that the supervisor authority has to oversee and intervene in banks functioning. Also } \\
\text { constructed for three periods (1998-2000, 2001-2003 and 2004-2006), using data from the surveys on } \\
\text { bank regulation and supervision conducted by the World Bank. In our data, the index ranges from } 4 \\
\text { to } 15.5 \text {. }\end{array}$ & $\begin{array}{l}\text { Barth et al. (2001, } \\
\text { 2006, 2008). }\end{array}$ \\
\hline Private Monitoring & $\begin{array}{l}\text { It is the Private Monitoring Index of Barth et al. (2006). It gives a measure of the degree to which } \\
\text { banks are exposed to external monitoring, apart from official regulatory and supervisory oversight. It } \\
\text { comprises regulatory requirements of information and accounting disclosure, external auditing, } \\
\text { depositor protection, use of subordinated debt, and discipline. The index was constructed for three } \\
\text { periods (1998-2000, 2001-2003 and 2004-2006), using data from the surveys on bank regulation and } \\
\text { supervision conducted by the World Bank. Higher values of the index represent more regulations } \\
\text { promoting the private monitoring of banks. }\end{array}$ & $\begin{array}{l}\text { Barth et al. (2001, } \\
\text { 2006, 2008). }\end{array}$ \\
\hline Financial Development & $\begin{array}{l}\text { A proxy of a lender's country financial development, constructed by Beck et al. (2000), using raw data } \\
\text { from the IMF's International Financial Statistics, October } 2008 \text {. This variable is given by the total } \\
\text { credit to the private sector by deposit money banks, as a share of GDP. It is available for each year of } \\
\text { the period. Higher values of this variable should correspond to more developed financial systems. }\end{array}$ & Beck et al. (2000). \\
\hline
\end{tabular}




\begin{tabular}{|c|c|c|}
\hline Variable & Description & Source \\
\hline Log (Number of Banks) & $\begin{array}{l}\text { It is the natural logarithm of the number of commercial banks in the country, made available by Barth } \\
\text { et al. (2001, 2006, 2008), based on the surveys on bank regulation and supervision conducted by the } \\
\text { World Bank. }\end{array}$ & $\begin{array}{l}\text { Barth et al. }(2001 \text {, } \\
\text { 2006, 2008). }\end{array}$ \\
\hline Rule of Law & $\begin{array}{l}\text { It is a country governance indicator constructed by Kaufmann et al. (2008) measuring perceptions of } \\
\text { the extent to which agents have confidence in and abide by the rules of society, and in particular the } \\
\text { quality of contract enforcement, property rights, the police, and the courts, as well as the likelihood of } \\
\text { crime and violence. The authors rely on multiple sources to construct a weighted aggregate indicator. }\end{array}$ & $\begin{array}{l}\text { Kaufmann et al. } \\
\text { (2008). }\end{array}$ \\
\hline \multicolumn{3}{|l|}{ Borrower country specific } \\
\hline Creditor Rights & $\begin{array}{l}\text { It is the index of La Porta et al. (1998), which measures a country's level of legal protection of lenders, } \\
\text { against expropriation by borrowers. It is assumed constant along the period from } 1997 \text { to } 2006 \text {. If it is } \\
\text { not available for a country, zero is assigned to this variable, and a separate indicator for creditor rights } \\
\text { index missing is included. }\end{array}$ & La Porta et al. (1998) \\
\hline $\log (\mathrm{GDP})$ & $\begin{array}{l}\text { The natural logarithm of the annual country's Gross Domestic Product (GDP), where GDP is given in } \\
\text { billions of US Dollars. This variable is supposed to measure the size of a country's economy. }\end{array}$ & $\begin{array}{l}\text { IMF (International } \\
\text { Financial Statistics) }\end{array}$ \\
\hline Log (GDP per capita) & $\begin{array}{l}\text { The natural logarithm of the annual country's GDP per capita. This variable is relied as a measure of a } \\
\text { country's economic development. }\end{array}$ & $\begin{array}{l}\text { IMF (International } \\
\text { Financial Statistics) }\end{array}$ \\
\hline GDP growth & $\begin{array}{l}\text { The percent growth in a country's GDP from the previous year to the current year. This variable } \\
\text { reflects a country's business cycle. }\end{array}$ & $\begin{array}{l}\text { IMF (International } \\
\text { Financial Statistics) }\end{array}$ \\
\hline Sovereign Credit Risk & $\begin{array}{l}\text { It is an index ranging from } 1 \text { to } 24 \text {, representing the borrower's country Fitch Sovereign Rating on } \\
\text { foreign currency, long term debt. Higher values of the index represent higher risk. It is available for } \\
\text { each year. }\end{array}$ & Fitch Ratings. \\
\hline
\end{tabular}




\begin{tabular}{|c|c|c|}
\hline Variable & Description & Source \\
\hline \multicolumn{3}{|l|}{ Lender specific } \\
\hline Log (Assets) & $\begin{array}{l}\text { The natural logarithm of the total assets of the bank. It is a measure of the size of the bank. Available } \\
\text { for each year. }\end{array}$ & Bankscope. \\
\hline Leverage & It is the ratio of total book value of liabilities to total book value of assets. It is available for each year. & Bankscope. \\
\hline Same country & A dummy variable that indicates if the loan was made to a borrower in the same country as the lender. & LPC DealScan \\
\hline \multicolumn{3}{|l|}{ Loan specific } \\
\hline Log (Loan Amount) & It is the natural logarithm of the loan deal amount, expressed in US Dollars. & LPC DealScan. \\
\hline Loan Purpose dummies & $\begin{array}{l}\text { These are } 7 \text { indicators of the most common specific purposes of the loan, which accounts for } 82 \% \text { of } \\
\text { the loans in the sample. These purposes are: Acquisition line, CP backup, Corporate Purposes, Debt } \\
\text { Repayment, LBO/MBO, Takeover, and Working Capital. }\end{array}$ & LPC DealScan. \\
\hline Loan Type dummies & $\begin{array}{l}\text { Five variables, accounting for } 77 \% \text { of the loans in the sample, indicating the most common types of } \\
\text { deals: 364-day facility, Term Loan, and Revolver line }>=1 \text { year. }\end{array}$ & LPC DealScan. \\
\hline
\end{tabular}


TABLES AND FIGURES

Table 1 - Descriptive Statistics

\begin{tabular}{|c|c|c|c|c|c|c|c|c|c|c|}
\hline Variable & Obs & Mean & $\begin{array}{c}\text { Std. } \\
\text { Deviation }\end{array}$ & Minimum & Maximum & $\begin{array}{c}\text { Percentile } \\
10 \%\end{array}$ & $\begin{array}{c}\text { Percentile } \\
25 \%\end{array}$ & Median & $\begin{array}{c}\text { Percentile } \\
75 \%\end{array}$ & $\begin{array}{c}\text { Percentile } \\
90 \%\end{array}$ \\
\hline Spread (basis points) & 32,354 & 188.80 & 172.98 & -295 & 15,000 & 40 & 75 & 155 & 250 & 350 \\
\hline Log of Maturity (months) & 41,965 & 3.66 & 0.82 & 0 & 10.09 & 2.48 & 3.18 & 4.01 & 4.09 & 4.43 \\
\hline Capital & 46,453 & 6.38 & 1.25 & 2 & 10 & 5 & 6 & 6 & 7 & 7 \\
\hline Official & 46,453 & 11.14 & 2.36 & 4 & 14 & 7 & 9 & 12 & 13 & 13 \\
\hline Private Monitoring & 46,453 & 8.79 & 1.36 & 5 & 11 & 7 & 8 & 9 & 10 & 10 \\
\hline Log of Deal Amount & 46,453 & 18.76 & 1.47 & 0 & 24.61 & 16.86 & 17.81 & 18.81 & 19.74 & 20.61 \\
\hline Lender Size (Log of Assets) & 46,453 & 20.03 & 1.06 & 13.09 & 21.40 & 18.75 & 19.62 & 20.27 & 20.81 & 21.10 \\
\hline Lender Leverage & 46,453 & 0.94 & 0.03 & 0.51 & 1.25 & 0.91 & 0.92 & 0.94 & 0.96 & 0.97 \\
\hline Borrower Rating Score* & 46,453 & 1.22 & 2.13 & 0 & 6 & 0 & 0 & 0 & 3 & 5 \\
\hline Creditor Rights & 46,453 & 1.49 & 1.00 & 0 & 4 & 1 & 1 & 1 & 2 & 3 \\
\hline Financial Development & 46,453 & 0.84 & 0.42 & 0 & 2.01 & 0.48 & 0.52 & 0.85 & 1.10 & 1.45 \\
\hline Log of GDP & 46,453 & 8.06 & 1.56 & 1.05 & 9.49 & 5.70 & 7.03 & 9.08 & 9.26 & 9.43 \\
\hline Log of GDP per capita & 46,453 & 10.19 & 0.75 & 5.95 & 11.41 & 9.51 & 10.22 & 10.46 & 10.54 & 10.64 \\
\hline GDP growth & 46,453 & 3.06 & 1.81 & -13.13 & 30.55 & 0.88 & 1.99 & 3.04 & 3.85 & 4.53 \\
\hline Sovereign Rating Score & 46,453 & 2.43 & 2.87 & 1 & 24 & 1 & 1 & 1 & 3 & 6 \\
\hline Same Country & 46,453 & 0.63 & 0.48 & 0 & 1 & 0 & 0 & 1 & 1 & 1 \\
\hline
\end{tabular}

* Zero if unrated. 
Table 2 - Lender Country Descriptive Statistics (Mean of country-specific variables in the 1998-2006 period)

\begin{tabular}{|c|c|c|c|c|c|c|c|}
\hline & Country & Capital & Official & $\begin{array}{c}\text { Private } \\
\text { Monitoring }\end{array}$ & $\begin{array}{c}\text { Financial } \\
\text { Development }\end{array}$ & $\begin{array}{c}\text { Rule of } \\
\text { Law }\end{array}$ & $\begin{array}{l}\text { Number } \\
\text { of Banks }\end{array}$ \\
\hline 1 & ARGENTINA & 7.5 & 9.8 & 8.3 & 0.17 & -0.37 & 88 \\
\hline 2 & AUSTRALIA & 6.4 & 11.5 & 9.8 & 0.88 & 1.77 & 52 \\
\hline 3 & AUSTRIA & 7.8 & 12.1 & 6.0 & 1.03 & 1.83 & 921 \\
\hline 4 & BELGIUM & 6.6 & 11.1 & 7.0 & 0.75 & 1.41 & 112 \\
\hline 5 & BRAZIL & 6.6 & 13.7 & 8.7 & 0.30 & -0.34 & 181 \\
\hline 6 & CANADA & 4.0 & 7.5 & 9.0 & 1.02 & 1.77 & 63 \\
\hline 7 & CHILE & 5.6 & 10.6 & 7.3 & 0.59 & 1.16 & 28 \\
\hline 8 & DENMARK & 7.1 & 8.9 & 9.3 & 1.10 & 1.87 & 181 \\
\hline 9 & EGYPT & 5.0 & 13.2 & 9.0 & 0.48 & -0.06 & 41 \\
\hline 10 & FINLAND & 4.7 & 7.7 & 9.1 & 0.59 & 1.89 & 10 \\
\hline 11 & FRANCE & 6.0 & 7.3 & 6.2 & 0.86 & 1.35 & 366 \\
\hline 12 & GERMANY & 6.3 & 8.8 & 7.5 & 1.13 & 1.70 & 1999 \\
\hline 13 & GREECE & 4.9 & 10.6 & 7.2 & 0.57 & 0.74 & 27 \\
\hline 14 & HONG KONG & 6.0 & 11.0 & 8.5 & 1.53 & 1.18 & 164 \\
\hline 15 & INDIA & 7.6 & 9.2 & 6.9 & 0.29 & 0.12 & 96 \\
\hline 16 & INDONESIA & 5.9 & 12.3 & 8.4 & 0.28 & -0.85 & 148 \\
\hline 17 & IRELAND & 4.9 & 10.5 & 9.2 & 1.09 & 1.61 & 53 \\
\hline 18 & ISRAEL & 5.5 & 8.3 & 9.6 & 0.80 & 0.88 & 22 \\
\hline 19 & ITALY & 5.4 & 6.6 & 7.2 & 0.74 & 0.72 & 845 \\
\hline 20 & JAPAN & 6.4 & 12.0 & 9.4 & 1.44 & 1.39 & 248 \\
\hline 21 & JORDAN & 7.7 & 10.1 & 7.4 & 0.72 & 0.37 & 20 \\
\hline 22 & KOREA (South) & 4.5 & 10.5 & 10.0 & 0.79 & 0.72 & 20 \\
\hline 23 & MALAYSIA & 3.9 & 11.6 & 9.3 & 1.28 & 0.46 & 29 \\
\hline 24 & MEXICO & 7.4 & 9.5 & 7.9 & 0.17 & -0.45 & 38 \\
\hline 25 & NETHERLANDS & 5.3 & 7.1 & 8.2 & 1.55 & 1.75 & 586 \\
\hline 26 & NORWAY & 7.5 & 8.7 & 7.5 & 0.70 & 1.93 & 15 \\
\hline 27 & PAKISTAN & 8.5 & 13.3 & 8.5 & 0.24 & -0.82 & 38 \\
\hline 28 & PHILIPPINES & 5.6 & 11.3 & 8.5 & 0.35 & -0.46 & 45 \\
\hline 29 & PORTUGAL & 6.8 & 13.6 & 7.5 & 1.22 & 1.16 & 59 \\
\hline 30 & SINGAPORE & 7.2 & 9.6 & 8.9 & 1.03 & 1.62 & 125 \\
\hline 31 & SOUTH AFRICA & 8.3 & 6.4 & 9.2 & 0.65 & 0.15 & 51 \\
\hline 32 & SPAIN & 9.6 & 9.6 & 8.3 & 1.03 & 1.25 & 286 \\
\hline 33 & SWEDEN & 2.9 & 6.3 & 6.9 & 0.74 & 1.83 & 25 \\
\hline 34 & SWITZERLAND & 6.2 & 13.6 & 8.1 & 1.61 & 1.98 & 370 \\
\hline 35 & TAIWAN & 5.8 & 11.3 & 8.3 & & 0.84 & 40 \\
\hline 36 & THAILAND & 5.6 & 9.7 & 8.3 & 1.14 & 0.24 & 26 \\
\hline 37 & UNITED KINGDOM & 6.7 & 10.1 & 9.6 & 1.34 & 1.73 & 394 \\
\hline 38 & USA & 6.7 & 13.0 & 9.2 & 0.51 & 1.60 & 8697 \\
\hline 39 & VENEZUELA & 3.9 & 12.1 & 5.6 & 0.10 & -0.90 & 24 \\
\hline
\end{tabular}


Table 3 - Borrower Country Descriptive Statistics (Number of loans and mean of variables across the 1998-2006 period)

\begin{tabular}{|c|c|c|c|c|c|c|c|}
\hline & Country & Loans & $\begin{array}{l}\text { Creditor } \\
\text { Rights }\end{array}$ & GDP & $\begin{array}{l}\text { GDP per } \\
\text { capita }\end{array}$ & $\begin{array}{l}\text { GDP } \\
\text { growth }\end{array}$ & $\begin{array}{c}\text { Sovereign } \\
\text { Score }\end{array}$ \\
\hline 1 & Argentina & 178 & 1 & 220 & 5,939 & 2.80 & 18.89 \\
\hline 2 & Australia & 1,218 & 1 & 500 & 25,346 & 3.55 & 2.56 \\
\hline 3 & Austria & 42 & 3 & 241 & 29,761 & 2.26 & 1.00 \\
\hline 4 & Azerbaijan & 5 & - & 8 & 970 & 12.28 & 12.25 \\
\hline 5 & Bahrain & 19 & - & 9 & 13,444 & 6.51 & 8.00 \\
\hline 6 & Belgium & 128 & 2 & 292 & 28,156 & 2.33 & 3.11 \\
\hline 7 & Bolivia & 4 & - & 9 & 994 & 3.26 & 16.00 \\
\hline 8 & Brazil & 356 & 1 & 718 & 4,096 & 2.57 & 13.67 \\
\hline 9 & Bulgaria & 19 & - & 18 & 2,311 & 3.89 & 11.71 \\
\hline 10 & Cameroon & 2 & - & 13 & 766 & 4.05 & 15.00 \\
\hline 11 & Canada & 1,490 & 1 & 837 & 26,670 & 3.46 & 2.00 \\
\hline 12 & Chile & 213 & 2 & 88 & 5,653 & 3.94 & 6.78 \\
\hline 13 & China & 293 & - & 1,549 & 1,205 & 9.21 & 6.89 \\
\hline 14 & Colombia & 51 & 0 & 97 & 2,241 & 2.64 & 11.22 \\
\hline 15 & Costa Rica & 8 & - & 17 & 4,256 & 5.34 & 12.00 \\
\hline 16 & Croatia & 38 & - & 27 & 6,054 & 4.00 & 10.22 \\
\hline 17 & Cyprus & 5 & - & 12 & 16,970 & 3.75 & 4.50 \\
\hline 18 & Czech Republic & 67 & - & 84 & 8,233 & 2.87 & 7.56 \\
\hline 19 & Denmark & 64 & 3 & 201 & 37,423 & 2.17 & 1.67 \\
\hline 20 & Dominican Rep. & 1 & - & 21 & 2,548 & 6.00 & 14.00 \\
\hline 21 & Ecuador & 4 & 4 & 27 & 2,082 & 3.37 & 16.67 \\
\hline 22 & Egypt & 46 & 4 & 89 & 1,350 & 5.03 & 10.56 \\
\hline 23 & El Salvador & 9 & - & 14 & 2,209 & 2.91 & 11.00 \\
\hline 24 & Estonia & 7 & - & 9 & 6,445 & 7.81 & 7.50 \\
\hline 25 & Finland & 140 & 1 & 153 & 29,366 & 3.77 & 1.11 \\
\hline 26 & France & 1,225 & 0 & 1,675 & 27,987 & 2.31 & 1.00 \\
\hline 27 & Germany & 770 & 3 & 2,323 & 28,212 & 1.44 & 1.00 \\
\hline 28 & Ghana & 8 & - & 8 & 406 & 4.89 & 14.50 \\
\hline 29 & Greece & 195 & 1 & 175 & 15,898 & 4.09 & 6.56 \\
\hline 30 & Hong Kong & 580 & 4 & 170 & 25,265 & 3.74 & 4.33 \\
\hline 31 & Hungary & 51 & - & 72 & 7,074 & 4.42 & 7.67 \\
\hline 32 & Iceland & 19 & - & 11 & 36,989 & 4.60 & 4.00 \\
\hline 33 & India & 239 & 4 & 559 & 538 & 6.53 & 11.14 \\
\hline 34 & Indonesia & 109 & 4 & 216 & 1,019 & 2.69 & 14.89 \\
\hline 35 & Iran & 39 & - & 134 & 2,042 & 4.71 & 13.75 \\
\hline 36 & Ireland & 94 & 1 & 135 & 34,184 & 7.24 & 1.11 \\
\hline 37 & Israel & 24 & 4 & 118 & 18,274 & 3.58 & 7.00 \\
\hline 38 & Italy . & 406 & 2 & 1,393 & 24,257 & 1.50 & 3.44 \\
\hline 39 & Jamaica & 2 & - & 8 & 3,133 & 0.92 & 14.00 \\
\hline 40 & Japan & 6,069 & 2 & 4,299 & 33,819 & 1.12 & 2.44 \\
\hline 41 & Kazakhstan & 31 & - & 34 & 2,249 & 7.48 & 11.44 \\
\hline 42 & Korea (South) & 699 & 3 & 583 & 12,286 & 4.37 & 7.22 \\
\hline
\end{tabular}

\begin{tabular}{|c|c|c|c|c|c|c|c|}
\hline & Country & Loans & $\begin{array}{c}\text { Creditor } \\
\text { Rights }\end{array}$ & GDP & $\begin{array}{c}\text { GDP per } \\
\text { capita }\end{array}$ & $\begin{array}{c}\text { GDP } \\
\text { growth }\end{array}$ & $\begin{array}{c}\text { Sovereign } \\
\text { Score } \\
\end{array}$ \\
\hline 43 & Kuwait & 15 & - & 48 & 18,479 & 5.80 & 4.78 \\
\hline 44 & Latvia & 4 & - & 11 & 4,551 & 7.75 & 8.22 \\
\hline 45 & Lithuania & 11 & - & 17 & 4,799 & 6.54 & 9.22 \\
\hline 46 & Luxembourg & 51 & - & 27 & 59,068 & 5.40 & 1.00 \\
\hline 47 & Malaysia & 412 & 4 & 107 & 4,401 & 4.42 & 8.67 \\
\hline 48 & Mali & 3 & - & 4 & 330 & 5.09 & 16.00 \\
\hline 49 & Malta & 3 & - & 5 & 11,753 & 1.29 & 6.00 \\
\hline 50 & Mexico & 381 & 0 & 608 & 6,089 & 3.62 & 10.56 \\
\hline 51 & Netherlands & 558 & 2 & 488 & 30,389 & 2.59 & 1.00 \\
\hline 52 & New Zealand & 129 & 3 & 73 & 18,396 & 3.04 & 2.20 \\
\hline 53 & Nigeria & 3 & 4 & 67 & 518 & 7.32 & 13.00 \\
\hline 54 & Norway & 197 & 2 & 213 & 46,757 & 2.70 & 1.00 \\
\hline 55 & Panama & 32 & - & 13 & 4,226 & 5.08 & 11.00 \\
\hline 56 & Papua New Guinea & 8 & - & 4 & 747 & 0.82 & 14.57 \\
\hline 57 & Peru & 39 & 0 & 64 & 2,447 & 3.88 & 12.38 \\
\hline 58 & Philippines & 190 & 0 & 83 & 1,051 & 4.18 & 11.50 \\
\hline 59 & Poland & 100 & - & 217 & 5,669 & 4.26 & 8.11 \\
\hline 60 & Portugal & 53 & 1 & 143 & 13,761 & 2.25 & 3.00 \\
\hline 61 & Romania & 57 & - & 59 & 2,706 & 2.66 & 13.11 \\
\hline 62 & Russia & 288 & - & 456 & 3,147 & 5.06 & 12.67 \\
\hline 63 & Saudi Arabia & 19 & - & 216 & 10,023 & 3.35 & 5.50 \\
\hline 64 & Serbia & 1 & - & 20 & 2,475 & 2.30 & 13.00 \\
\hline 65 & Singapore & 398 & 4 & 99 & 24,010 & 5.39 & 1.56 \\
\hline 66 & Slovakia & 30 & - & 31 & 5,731 & 4.37 & 9.75 \\
\hline 67 & Slovenia & 13 & - & 29 & 14,317 & 4.21 & 5.44 \\
\hline 68 & South Africa & 66 & 3 & 166 & 3,655 & 3.45 & 9.78 \\
\hline 69 & Spain & 757 & 2 & 797 & 19,083 & 3.83 & 1.78 \\
\hline 70 & Sri Lanka & 1 & 3 & 18 & 973 & 4.87 & 13.00 \\
\hline 71 & Sweden & 250 & 2 & 291 & 32,532 & 3.22 & 2.22 \\
\hline 72 & Switzerland & 209 & 1 & 304 & 42,144 & 1.92 & 1.00 \\
\hline 73 & Taiwan & 1,039 & 2 & 315 & 14,037 & 4.38 & 5.00 \\
\hline 74 & Thailand & 366 & 3 & 144 & 2,270 & 2.79 & 9.44 \\
\hline 75 & Tunisia & 15 & - & 23 & 2,393 & 4.88 & 9.33 \\
\hline 76 & Turkey & 79 & 2 & 316 & 4,907 & 4.44 & 14.00 \\
\hline 77 & Turkmenistan & 1 & - & 9 & 1,934 & 12.24 & 15.00 \\
\hline 78 & USA & 23,432 & 1 & 10,501 & 36,553 & 3.12 & 1.00 \\
\hline 79 & Ukraine & 30 & - & 54 & 1,134 & 4.65 & 14.17 \\
\hline 80 & United Kingdom & 2,167 & 4 & 1,737 & 29,236 & 2.85 & 1.00 \\
\hline 81 & Uruguay & 10 & 2 & 18 & 5,350 & 1.84 & 10.00 \\
\hline 82 & Venezuela & 53 & - & 113 & 4,536 & 3.01 & 14.00 \\
\hline \multirow[t]{2}{*}{83} & Vietnam & 16 & - & 38 & 476 & 7.12 & 13.00 \\
\hline & Total & 46,453 & & & & & \\
\hline
\end{tabular}


Table 4 - Correlation Matrix

(Sample: 46,453 loans made by 278 banks of 39 countries, in the 1998-2006 period)

\begin{tabular}{|c|c|c|c|c|c|c|c|c|c|c|c|c|c|}
\hline & Spread & Matur. & Capital & Official & $\begin{array}{l}\text { Private } \\
\text { Monit. }\end{array}$ & $\begin{array}{c}\text { Deal } \\
\text { amount }\end{array}$ & $\begin{array}{c}\text { Lender } \\
\text { Size }\end{array}$ & $\begin{array}{l}\text { Lender } \\
\text { Lever. }\end{array}$ & $\begin{array}{l}\text { Borr. } \\
\text { Score }\end{array}$ & $\begin{array}{l}\text { Credit. } \\
\text { Rights }\end{array}$ & $\begin{array}{c}\text { Fin. } \\
\text { Devel. }\end{array}$ & $\begin{array}{r}\text { Log of } \\
\text { GDP pc }\end{array}$ & $\begin{array}{c}\text { GDP } \\
\text { Growth }\end{array}$ \\
\hline Spread & 1 & & & & & & & & & & & & \\
\hline Log of Maturity & 0.15 & 1 & & & & & & & & & & & \\
\hline Capital & -0.04 & 0.10 & 1 & & & & & & & & & & \\
\hline Official & 0.03 & -0.11 & 0.26 & 1 & & & & & & & & & \\
\hline Private Monitoring & 0.05 & -0.03 & 0.12 & 0.43 & 1 & & & & & & & & \\
\hline Log of Deal Amount & -0.17 & 0.06 & 0.08 & -0.13 & -0.03 & 1 & & & & & & & \\
\hline Lender Size & 0.00 & -0.05 & 0.19 & -0.01 & 0.09 & 0.20 & 1 & & & & & & \\
\hline Lender Leverage & -0.08 & 0.03 & -0.14 & -0.56 & -0.39 & 0.11 & 0.24 & 1 & & & & & \\
\hline Borrower Rating Score & 0.04 & 0.01 & 0.06 & 0.05 & 0.01 & 0.38 & 0.17 & -0.04 & 1 & & & & \\
\hline (borrower) Cred. Rights & -0.06 & 0.06 & -0.07 & -0.09 & 0.03 & -0.04 & -0.12 & 0.16 & -0.21 & 1 & & & \\
\hline (lender) Fin. Develop. & -0.03 & 0.03 & -0.09 & -0.33 & 0.10 & 0.12 & 0.23 & 0.50 & -0.04 & 0.27 & 1 & & \\
\hline (borrower) Log GDP pc & 0.02 & -0.09 & 0.08 & 0.17 & 0.17 & 0.07 & 0.32 & -0.10 & 0.17 & -0.13 & -0.05 & 1 & \\
\hline (borrower) GDP growth & -0.04 & 0.13 & 0.14 & -0.06 & -0.12 & 0.02 & -0.15 & -0.05 & -0.02 & $0.00 *$ & -0.09 & -0.33 & 1 \\
\hline (borrower) Sov. Score & 0.01 & 0.06 & -0.08 & -0.12 & -0.10 & -0.13 & -0.23 & 0.12 & -0.20 & 0.11 & 0.07 & -0.88 & 0.20 \\
\hline
\end{tabular}

* Not Significant (at the $5 \%$ level). 
Table 5 - Relationship between Bank Regulations and Loan Contracts Characteristics Dependent variables in columns. OLS regressions ${ }^{+}$over the period 1998-2006. Robust standard errors clustered by banks are in parentheses. Constant, year dummies and other loan-specific controls (industry sector, loan purpose and loan type) are omitted.

\begin{tabular}{|c|c|c|c|c|c|}
\hline \multirow{2}{*}{\multicolumn{2}{|c|}{$\begin{array}{c}\text { Explanatory } \\
\text { Variables }\end{array}$}} & \multicolumn{2}{|c|}{ Spread } & \multicolumn{2}{|c|}{$\log _{\text {of Maturity }}{ }^{a}$} \\
\hline & & $R 1$ & $R 2$ & $R 3$ & $R 4$ \\
\hline & \multicolumn{5}{|c|}{ Lender Country's Bank Regulations } \\
\hline 1 & Capital & $\begin{array}{c}-6.63 * * * \\
(2.05)\end{array}$ & $\begin{array}{l}19.26^{*} \\
(10.85)\end{array}$ & $\begin{array}{c}4.10 * * * \\
(1.00)\end{array}$ & $\begin{array}{c}-7.97 * * \\
(3.39)\end{array}$ \\
\hline 2 & Capital $^{\wedge} 2$ & & $\begin{array}{c}-2.05 * * \\
(0.83) \\
\end{array}$ & & $\begin{array}{c}0.95 * * * \\
(0.28) \\
\end{array}$ \\
\hline 3 & Official & $\begin{array}{l}-0.02 \\
(2.58)\end{array}$ & $\begin{array}{l}-0.74 \\
(2.69)\end{array}$ & $\begin{array}{c}-2.12 * * * \\
(0.58)\end{array}$ & $\begin{array}{c}-1.72 * * * \\
(0.55)\end{array}$ \\
\hline \multirow[t]{2}{*}{4} & $\begin{array}{l}\text { Private } \\
\text { Monitoring }\end{array}$ & $\begin{array}{c}1.62 \\
(3.26) \\
\end{array}$ & $\begin{array}{c}0.20 \\
(3.08)\end{array}$ & $\begin{array}{l}-0.31 \\
(0.98)\end{array}$ & $\begin{array}{c}0.28 \\
(0.92) \\
\end{array}$ \\
\hline & \multicolumn{5}{|c|}{ Lender, borrower and loan specific } \\
\hline 5 & $\begin{array}{l}\text { Lender Log } \\
\text { (Assets) }\end{array}$ & $\begin{array}{c}0.32 \\
(3.13)\end{array}$ & $\begin{array}{l}-0.98 \\
(3.04)\end{array}$ & $\begin{array}{c}-2.60 * * \\
(1.01)\end{array}$ & $\begin{array}{l}-1.99 * \\
(1.06)\end{array}$ \\
\hline 6 & $\begin{array}{l}\text { Lender } \\
\text { Leverage }\end{array}$ & $\begin{array}{l}-2.24 \\
(2.61)\end{array}$ & $\begin{array}{l}-1.94 \\
(2.61)\end{array}$ & $\begin{array}{l}-0.85 \\
(0.80)\end{array}$ & $\begin{array}{l}-0.91 \\
(0.79)\end{array}$ \\
\hline 7 & $\begin{array}{l}\text { Borrower } \\
\text { Rating } \\
\end{array}$ & $\begin{array}{c}6.81 * * * \\
(0.79) \\
\end{array}$ & $\begin{array}{c}6.78^{* * *} \\
(0.77) \\
\end{array}$ & $\begin{array}{c}2.46^{* * *} \\
(0.50) \\
\end{array}$ & $\begin{array}{c}2.46 * * * \\
(0.49) \\
\end{array}$ \\
\hline 8 & $\begin{array}{l}\text { Log (Deal } \\
\text { Amount) }\end{array}$ & $\begin{array}{c}-20.83^{* * * *} \\
(1.27)\end{array}$ & $\begin{array}{c}-20.90 * * * \\
(1.27)\end{array}$ & $\begin{array}{c}6.47^{* * * *} \\
(1.08)\end{array}$ & $\begin{array}{c}6.41 * * * \\
(1.08)\end{array}$ \\
\hline \multirow[t]{2}{*}{9} & Same Country & $\begin{array}{c}-12.10 * * \\
(5.15) \\
\end{array}$ & $\begin{array}{c}-12.15 * * \\
(5.11) \\
\end{array}$ & $\begin{array}{l}-1.71 \\
(3.50) \\
\end{array}$ & $\begin{array}{l}-1.37 \\
(3.46) \\
\end{array}$ \\
\hline & \multicolumn{5}{|c|}{ Borrower Country Specific (except $\left.{ }^{b}\right)$} \\
\hline 10 & Creditor Rights & $\begin{array}{l}-1.91 \\
(1.76) \\
\end{array}$ & $\begin{array}{l}-2.35 \\
(1.72) \\
\end{array}$ & $\begin{array}{l}-0.16 \\
(1.01) \\
\end{array}$ & $\begin{array}{c}0.10 \\
(0.96) \\
\end{array}$ \\
\hline 11 & $\begin{array}{l}\text { Creditor Rights } \\
\text { missing }\end{array}$ & $\begin{array}{c}-2.54 \\
(10.03) \\
\end{array}$ & $\begin{array}{l}-5.37 \\
(9.90) \\
\end{array}$ & $\begin{array}{l}-0.23 \\
(4.88) \\
\end{array}$ & $\begin{array}{c}1.13 \\
(4.82) \\
\end{array}$ \\
\hline 12 & $\log ($ GDP $)$ & $\begin{array}{c}19.35 * * * \\
(1.94)\end{array}$ & $\begin{array}{c}18.98 * * * \\
(1.88)\end{array}$ & $\begin{array}{c}-4.48^{* * *} \\
(0.82)\end{array}$ & $\begin{array}{c}-4.29 * * * \\
(0.81)\end{array}$ \\
\hline 13 & GDP growth & $\begin{array}{c}-4.33 * * * \\
(1.05) \\
\end{array}$ & $\begin{array}{c}-4.20 * * * \\
(1.05) \\
\end{array}$ & $\begin{array}{c}1.67 * * * \\
(0.49)\end{array}$ & $\begin{array}{c}1.58 * * * \\
(0.49)\end{array}$ \\
\hline 14 & $\begin{array}{l}\text { Sovereign } \\
\text { Credit Risk }\end{array}$ & $\begin{array}{c}7.15 * * * \\
(1.05) \\
\end{array}$ & $\begin{array}{c}7.09^{* * *} \\
(1.04) \\
\end{array}$ & $\begin{array}{c}-2.82 * * * \\
(0.66) \\
\end{array}$ & $\begin{array}{c}-2.79 * * * \\
(0.66) \\
\end{array}$ \\
\hline 15 & $\begin{array}{l}\text { Lender Country } \\
\text { Fin. Develop. }\end{array}$ & $\begin{array}{c}-12.81 \\
(10.98) \\
\end{array}$ & $\begin{array}{l}-14.75 \\
(11.14) \\
\end{array}$ & $\begin{array}{c}3.03 \\
(3.45) \\
\end{array}$ & $\begin{array}{c}4.05 \\
(3.59) \\
\end{array}$ \\
\hline Obs & rvations & 32,354 & 32,354 & 41,965 & 41,965 \\
\hline R-S & uared & 0.21 & 0.21 & 0.35 & 0.35 \\
\hline
\end{tabular}

${ }^{+}$Significance levels: *** $1 \%, * * 5 \% ; * 10 \%$

${ }^{\text {a }}$ Coefficients and standard errors of Log (Maturity) regressions are multiplied by 100 . 
Table 6 -Effect of Interactions between Bank Regulations on Loan Spread and Maturity Dependent variables: Spread and Log(Maturity). OLS regressions ${ }^{+}$over the period 1998-2006. Robust standard errors clustered by banks are in parentheses. Constant, year dummies and other loan-specific controls (industry sector, loan purpose and loan type) are omitted.

\begin{tabular}{|c|c|c|c|c|}
\hline \multirow{2}{*}{\multicolumn{2}{|c|}{ Explanatory Variables }} & \multirow{2}{*}{$\begin{array}{c}\text { Spread } \\
R 1\end{array}$} & \multicolumn{2}{|c|}{ Log of Maturity ${ }^{a}$} \\
\hline & & & $R 2$ & $R 3$ \\
\hline & \multicolumn{4}{|c|}{ Lender Country's Bank Regulations } \\
\hline 1 & Capital & $\begin{array}{c}47.07 * * * \\
(11.48)\end{array}$ & $\begin{array}{c}-16.39 * * * \\
(4.50)\end{array}$ & $\begin{array}{c}-12.91 * * * \\
(4.37)\end{array}$ \\
\hline 2 & Capital`2 $^{\wedge}$ & $\begin{array}{c}-1.71 * * \\
(0.84) \\
\end{array}$ & $\begin{array}{c}0.87 * * * \\
(0.31)\end{array}$ & $\begin{array}{c}0.78 * * * \\
(0.28)\end{array}$ \\
\hline 3 & Official & $\begin{array}{l}-1.20 \\
(2.26)\end{array}$ & $\begin{array}{c}-1.57 * * * \\
(0.56)\end{array}$ & $\begin{array}{c}-6.78 * * * \\
(2.18)\end{array}$ \\
\hline 4 & Private Monitoring & $\begin{array}{c}22.97 * * * \\
(6.15) \\
\end{array}$ & $\begin{array}{c}-6.32 * * \\
(2.51)\end{array}$ & $\begin{array}{c}0.72 \\
(0.93) \\
\end{array}$ \\
\hline 5 & Capital x Official & & & $\begin{array}{c}0.79 * * * \\
(0.30) \\
\end{array}$ \\
\hline \multirow[t]{2}{*}{6} & $\begin{array}{l}\text { Capital x Private } \\
\text { Monitoring } \\
\end{array}$ & $\begin{array}{c}-4.03 * * * \\
(1.29) \\
\end{array}$ & $\begin{array}{c}1.17 * * \\
(0.48)\end{array}$ & \\
\hline & \multicolumn{4}{|c|}{ Lender, borrower and loan specific } \\
\hline 7 & Lender Log (Assets) & $\begin{array}{c}1.08 \\
(3.15) \\
\end{array}$ & $\begin{array}{c}-2.52 * * \\
(1.11) \\
\end{array}$ & $\begin{array}{c}-2.17^{* *} \\
(1.06) \\
\end{array}$ \\
\hline 8 & Lender Leverage & $\begin{array}{l}-3.22 \\
(2.72)\end{array}$ & $\begin{array}{l}-0.55 \\
(0.74)\end{array}$ & $\begin{array}{l}-0.60 \\
(0.74)\end{array}$ \\
\hline 9 & Borrower Rating & $\begin{array}{c}6.72 * * * \\
(0.78) \\
\end{array}$ & $\begin{array}{c}2.48 * * * \\
(0.49)\end{array}$ & $\begin{array}{c}2.41 * * * \\
(0.48)\end{array}$ \\
\hline 10 & Log (Deal Amount) & $\begin{array}{c}-20.75 * * * \\
(1.25) \\
\end{array}$ & $\begin{array}{c}6.34 * * * \\
(1.09) \\
\end{array}$ & $\begin{array}{c}6.37 * * * \\
(1.08) \\
\end{array}$ \\
\hline \multirow[t]{2}{*}{11} & Same Country & $\begin{array}{c}-10.75 * * \\
(5.11) \\
\end{array}$ & $\begin{array}{l}-1.52 \\
(3.48) \\
\end{array}$ & $\begin{array}{l}-1.39 \\
(3.46) \\
\end{array}$ \\
\hline & \multicolumn{4}{|c|}{ Borrower Country Specific (except $\left.{ }^{a}\right)$} \\
\hline 12 & Creditor Rights & $\begin{array}{l}-2.49 \\
(1.74) \\
\end{array}$ & $\begin{array}{c}0.13 \\
(0.95) \\
\end{array}$ & $\begin{array}{c}0.29 \\
(0.93) \\
\end{array}$ \\
\hline 13 & Creditor Rights missing & $\begin{array}{l}-5.98 \\
(9.83) \\
\end{array}$ & $\begin{array}{c}1.28 \\
(4.83) \\
\end{array}$ & $\begin{array}{c}1.27 \\
(4.77) \\
\end{array}$ \\
\hline 14 & $\log (\mathrm{GDP})$ & $\begin{array}{c}18.73^{* * *} \\
(1.84) \\
\end{array}$ & $\begin{array}{c}-4.25 * * * \\
(0.81) \\
\end{array}$ & $\begin{array}{c}-4.28 * * * \\
(0.79) \\
\end{array}$ \\
\hline 15 & GDP growth & $\begin{array}{c}-4.43 * * * \\
(1.05) \\
\end{array}$ & $\begin{array}{c}1.61 * * * \\
(0.49) \\
\end{array}$ & $\begin{array}{c}1.53 * * * \\
(0.49) \\
\end{array}$ \\
\hline 16 & Sovereign Credit Risk & $\begin{array}{c}7.06 * * * \\
(1.02) \\
\end{array}$ & $\begin{array}{c}-2.76 * * * \\
(0.66) \\
\end{array}$ & $\begin{array}{c}-2.74 * * * \\
(0.65) \\
\end{array}$ \\
\hline 17 & $\begin{array}{l}\text { Lender Country Fin. } \\
\text { Develop. }^{\text {a }}\end{array}$ & $\begin{array}{c}-13.42 \\
(10.21) \\
\end{array}$ & $\begin{array}{c}3.91 \\
(3.70) \\
\end{array}$ & $\begin{array}{c}3.25 \\
(3.41) \\
\end{array}$ \\
\hline Obs & rvations & 32,354 & 41,965 & 41,965 \\
\hline R-s & uared & 0.21 & 0.35 & 0.35 \\
\hline
\end{tabular}


Table 7 -Bank Regulations and Loan Spread: sub-samples of high and low lender country Rule of Law, Financial Development and Competition.

Dependent variable: Spread. OLS regressions ${ }^{+}$over the period 1998-2006. Robust standard errors clustered by banks are in parentheses. Constant, year dummies and other loan-specific controls (industry sector, loan purpose and loan type) are omitted.

\begin{tabular}{|c|c|c|c|c|c|c|c|}
\hline \multirow{2}{*}{\multicolumn{2}{|c|}{$\begin{array}{c}\text { Explanatory } \\
\text { Variables }\end{array}$}} & \multicolumn{2}{|c|}{ Rule of Law } & \multicolumn{2}{|c|}{ Financial Development } & \multicolumn{2}{|c|}{ Competition } \\
\hline & & Low & High & Low & High & Low & High \\
\hline & \multicolumn{7}{|c|}{ Lender Country's Bank Regulations } \\
\hline 1 & Capital & $\begin{array}{l}-0.66 \\
(5.92) \\
\end{array}$ & $\begin{array}{c}-6.02 * * \\
(2.32) \\
\end{array}$ & $\begin{array}{l}-0.38 \\
(3.69) \\
\end{array}$ & $\begin{array}{c}-6.63 * * * \\
(1.81)\end{array}$ & $\begin{array}{c}-6.30 * * \\
(3.00) \\
\end{array}$ & $\begin{array}{c}-6.03 * * \\
(2.48) \\
\end{array}$ \\
\hline 2 & Official & $\begin{array}{c}11.76 * * \\
(4.55)\end{array}$ & $\begin{array}{c}0.34 \\
(2.87) \\
\end{array}$ & $\begin{array}{c}-6.63 * * \\
(2.94)\end{array}$ & $\begin{array}{l}-1.43 \\
(2.41) \\
\end{array}$ & $\begin{array}{c}0.13 \\
(2.64) \\
\end{array}$ & $\begin{array}{c}1.49 \\
(3.27) \\
\end{array}$ \\
\hline \multirow[t]{2}{*}{3} & $\begin{array}{l}\text { Private } \\
\text { Monitoring }\end{array}$ & $\begin{array}{l}-3.89 \\
(7.01) \\
\end{array}$ & $\begin{array}{c}1.48 \\
(3.30) \\
\end{array}$ & $\begin{array}{l}7.77 * \\
(4.04) \\
\end{array}$ & $\begin{array}{l}-1.71 \\
(2.94) \\
\end{array}$ & $\begin{array}{c}-12.75 * * \\
(5.91) \\
\end{array}$ & $\begin{array}{c}2.18 \\
(4.17) \\
\end{array}$ \\
\hline & \multicolumn{7}{|c|}{ Lender, borrower and loan specific } \\
\hline 4 & $\begin{array}{l}\text { Lender Log } \\
\text { (Assets) }\end{array}$ & $\begin{array}{c}-17.51 * * \\
(8.50)\end{array}$ & $\begin{array}{l}-1.16 \\
(3.86) \\
\end{array}$ & $\begin{array}{l}-2.21 \\
(6.05)\end{array}$ & $\begin{array}{c}-9.66 * * \\
(4.78) \\
\end{array}$ & $\begin{array}{c}-11.02 * * \\
(5.20) \\
\end{array}$ & $\begin{array}{l}-3.03 \\
(4.14) \\
\end{array}$ \\
\hline 5 & $\begin{array}{l}\text { Lender } \\
\text { Leverage }\end{array}$ & $\begin{array}{c}4.33^{* *} \\
(1.89) \\
\end{array}$ & $\begin{array}{l}-2.46 \\
(3.09) \\
\end{array}$ & $\begin{array}{l}-4.79 \\
(4.52) \\
\end{array}$ & $\begin{array}{c}4.56^{* *} \\
(1.94)\end{array}$ & $\begin{array}{c}4.41 * * * \\
(1.63)\end{array}$ & $\begin{array}{l}-1.83 \\
(2.91)\end{array}$ \\
\hline 6 & $\begin{array}{l}\text { Borrower } \\
\text { Rating } \\
\end{array}$ & $\begin{array}{c}3.96 \\
(10.44) \\
\end{array}$ & $\begin{array}{c}6.68 * * * \\
(0.78) \\
\end{array}$ & $\begin{array}{c}6.37 * * * \\
(1.10) \\
\end{array}$ & $\begin{array}{c}8.06 * * * \\
(1.40) \\
\end{array}$ & $\begin{array}{c}9.39 * * * \\
(1.81) \\
\end{array}$ & $\begin{array}{c}6.53 * * * \\
(0.82) \\
\end{array}$ \\
\hline 7 & $\begin{array}{l}\text { Log (Deal } \\
\text { Amount) }\end{array}$ & $\begin{array}{l}-5.51 \\
(4.77) \\
\end{array}$ & $\begin{array}{c}-21.49^{* * *} \\
(1.26)\end{array}$ & $\begin{array}{c}-23.35 * * * \\
(1.44) \\
\end{array}$ & $\begin{array}{c}-16.77 * * * \\
(2.05) \\
\end{array}$ & $\begin{array}{c}-13.74 * * * \\
(3.48) \\
\end{array}$ & $\begin{array}{c}-20.97 * * * \\
(1.29) \\
\end{array}$ \\
\hline \multirow[t]{2}{*}{8} & Same Country & $\begin{array}{c}-3.09 \\
(15.58) \\
\end{array}$ & $\begin{array}{c}-12.95 * * \\
(5.50) \\
\end{array}$ & $\begin{array}{c}-33.21 * * * \\
(10.92)\end{array}$ & $\begin{array}{c}-16.92 * * * \\
(6.20)\end{array}$ & $\begin{array}{c}9.69 \\
(10.35) \\
\end{array}$ & $\begin{array}{c}-15.50 * * \\
(6.22) \\
\end{array}$ \\
\hline & \multicolumn{7}{|c|}{ Borrower Country Specific (except $\left.{ }^{a}\right)$} \\
\hline 9 & Creditor Rights & $\begin{array}{c}-12.36^{*} \\
(7.03) \\
\end{array}$ & $\begin{array}{l}-2.65 \\
(2.03) \\
\end{array}$ & $\begin{array}{l}-5.76 \\
(4.21) \\
\end{array}$ & $\begin{array}{c}0.46 \\
(1.88) \\
\end{array}$ & $\begin{array}{l}-3.79 \\
(5.38) \\
\end{array}$ & $\begin{array}{l}-3.28 \\
(2.05) \\
\end{array}$ \\
\hline 10 & $\begin{array}{l}\text { Creditor Rights } \\
\text { missing }\end{array}$ & $\begin{array}{c}-89.88 * * * \\
(32.31) \\
\end{array}$ & $\begin{array}{c}0.15 \\
(9.96) \\
\end{array}$ & $\begin{array}{l}-10.10 \\
(11.22) \\
\end{array}$ & $\begin{array}{c}-11.53 \\
(12.53) \\
\end{array}$ & $\begin{array}{c}-75.33 * * * \\
(24.87) \\
\end{array}$ & $\begin{array}{c}-1.33 \\
(10.09) \\
\end{array}$ \\
\hline 11 & $\log (\mathrm{GDP})$ & $\begin{array}{c}10.92 * \\
(5.68) \\
\end{array}$ & $\begin{array}{c}18.51 * * * \\
(1.88)\end{array}$ & $\begin{array}{c}23.09 * * * \\
(2.90) \\
\end{array}$ & $\begin{array}{c}13.83 * * * \\
(1.81) \\
\end{array}$ & $\begin{array}{c}25.07 * * * \\
(3.53)\end{array}$ & $\begin{array}{c}17.67 * * * \\
(2.02) \\
\end{array}$ \\
\hline 12 & GDP growth & $\begin{array}{c}2.50 \\
(2.28) \\
\end{array}$ & $\begin{array}{c}-4.77 * * * \\
(1.07) \\
\end{array}$ & $\begin{array}{c}-6.23 * * * \\
(1.67) \\
\end{array}$ & $\begin{array}{l}-1.56 \\
(1.29) \\
\end{array}$ & $\begin{array}{c}2.48 \\
(1.70) \\
\end{array}$ & $\begin{array}{c}-4.69 * * * \\
(1.09) \\
\end{array}$ \\
\hline 13 & $\begin{array}{l}\text { Sovereign } \\
\text { Credit Risk } \\
\end{array}$ & $\begin{array}{c}11.27 * * * \\
(2.79) \\
\end{array}$ & $\begin{array}{c}6.57 * * * \\
(1.14) \\
\end{array}$ & $\begin{array}{c}5.48 * * * \\
(1.13)\end{array}$ & $\begin{array}{c}6.81 * * * \\
(1.40)\end{array}$ & $\begin{array}{c}14.57 * * * \\
(2.31) \\
\end{array}$ & $\begin{array}{c}6.17 * * * \\
(1.10) \\
\end{array}$ \\
\hline 14 & $\begin{array}{l}\text { Lender Country } \\
\text { Fin. Develop. }{ }^{\text {a }}\end{array}$ & $\begin{array}{c}105.19 * * \\
(47.36) \\
\end{array}$ & $\begin{array}{l}-12.41 \\
(11.39) \\
\end{array}$ & $\begin{array}{l}-14.06 \\
(66.91) \\
\end{array}$ & $\begin{array}{c}16.87 \\
(13.37) \\
\end{array}$ & $\begin{array}{c}51.59 \\
(35.21) \\
\end{array}$ & $\begin{array}{l}-12.95 \\
(12.52) \\
\end{array}$ \\
\hline $\mathrm{Obs}$ & rvations & 1,674 & 30,514 & 16,531 & 14,028 & 2,638 & 29,666 \\
\hline R-s & uared & 0.23 & 0.21 & 0.18 & 0.26 & 0.24 & 0.21 \\
\hline
\end{tabular}

${ }^{+}$Significance levels: $* * * 1 \%, * * 5 \% ; * 10 \%$ 
Table 8 -Lender Country Bank Regulations and Loan Maturity: sub-samples of high and low lender country Rule of Law, Financial Development and Competition.

Dependent variable: Log of Maturity. OLS regressions ${ }^{+}$over the period 1998-2006. Robust standard errors clustered by banks are in parentheses. Constant, year dummies and other loan-specific controls (industry sector, loan purpose and loan type) are omitted. All coefficients and standard errors are multiplied by 100 .

\begin{tabular}{|c|c|c|c|c|c|c|c|}
\hline \multirow{2}{*}{\multicolumn{2}{|c|}{$\begin{array}{c}\text { Explanatory } \\
\text { Variables }\end{array}$}} & \multicolumn{2}{|c|}{ Rule of Law } & \multicolumn{2}{|c|}{ Financial Development } & \multicolumn{2}{|c|}{ Competition } \\
\hline & & Low & High & Low & High & Low & High \\
\hline & \multicolumn{7}{|c|}{ Lender Country's Bank Regulations } \\
\hline 1 & Capital & $\begin{array}{l}-0.86 \\
(1.73)\end{array}$ & $\begin{array}{c}4.55 * * * \\
(1.30)\end{array}$ & $\begin{array}{l}-0.39 \\
(1.57)\end{array}$ & $\begin{array}{c}3.95 * * * \\
(0.59)\end{array}$ & $\begin{array}{l}-0.06 \\
(1.00)\end{array}$ & $\begin{array}{c}4.84 * * * \\
(1.50)\end{array}$ \\
\hline 2 & Official & $\begin{array}{l}-1.55 \\
(1.37) \\
\end{array}$ & $\begin{array}{c}-2.49 * * * \\
(0.64)\end{array}$ & $\begin{array}{l}-0.11 \\
(0.90) \\
\end{array}$ & $\begin{array}{c}-3.07 * * * \\
(0.85)\end{array}$ & $\begin{array}{c}-4.78 * * * \\
(1.17)\end{array}$ & $\begin{array}{c}-2.45 * * * \\
(0.76)\end{array}$ \\
\hline \multirow[t]{2}{*}{3} & $\begin{array}{l}\text { Private } \\
\text { Monitoring }\end{array}$ & $\begin{array}{c}-8.22 * * * \\
(2.22) \\
\end{array}$ & $\begin{array}{c}0.12 \\
(0.98) \\
\end{array}$ & $\begin{array}{c}-7.45 * * * \\
(1.73) \\
\end{array}$ & $\begin{array}{l}-1.55 \\
(0.95) \\
\end{array}$ & $\begin{array}{l}-1.82 \\
(1.94) \\
\end{array}$ & $\begin{array}{l}-0.11 \\
(1.22) \\
\end{array}$ \\
\hline & \multicolumn{7}{|c|}{ Lender, borrower and loan specific } \\
\hline 4 & $\begin{array}{l}\text { Lender Log } \\
\text { (Assets) }\end{array}$ & $\begin{array}{c}1.43 \\
(2.78) \\
\end{array}$ & $\begin{array}{c}-0.26 \\
(1.60) \\
\end{array}$ & $\begin{array}{l}-2.95 * \\
(1.51)\end{array}$ & $\begin{array}{c}-4.26 * * * \\
(1.31)\end{array}$ & $\begin{array}{l}-2.86 \\
(2.07) \\
\end{array}$ & $\begin{array}{c}0.01 \\
(1.57) \\
\end{array}$ \\
\hline 5 & $\begin{array}{l}\text { Lender } \\
\text { Leverage }\end{array}$ & $\begin{array}{c}0.90 \\
(0.62)\end{array}$ & $\begin{array}{l}-1.33 \\
(0.98) \\
\end{array}$ & $\begin{array}{l}-1.24 \\
(0.91) \\
\end{array}$ & $\begin{array}{c}2.28 * * * \\
(0.87)\end{array}$ & $\begin{array}{l}2.30 * * \\
(0.91)\end{array}$ & $\begin{array}{l}-1.50 \\
(0.95) \\
\end{array}$ \\
\hline 6 & $\begin{array}{l}\text { Borrower } \\
\text { Rating } \\
\end{array}$ & $\begin{array}{l}-3.04 \\
(2.19) \\
\end{array}$ & $\begin{array}{c}2.36^{* * *} \\
(0.48) \\
\end{array}$ & $\begin{array}{c}1.60^{* * *} \\
(0.36) \\
\end{array}$ & $\begin{array}{c}2.15 * * * \\
(0.53) \\
\end{array}$ & $\begin{array}{c}1.41 \\
(0.91) \\
\end{array}$ & $\begin{array}{c}2.40 * * * \\
(0.50) \\
\end{array}$ \\
\hline 7 & $\begin{array}{l}\text { Log (Deal } \\
\text { Amount) }\end{array}$ & $\begin{array}{c}8.98 * * * \\
(1.54) \\
\end{array}$ & $\begin{array}{c}5.96^{* * * *} \\
(1.14) \\
\end{array}$ & $\begin{array}{c}9.92 * * * \\
(1.27) \\
\end{array}$ & $\begin{array}{c}2.99 * * * \\
(0.68) \\
\end{array}$ & $\begin{array}{c}7.74 * * * \\
(1.47) \\
\end{array}$ & $\begin{array}{c}6.11 * * * \\
(1.14) \\
\end{array}$ \\
\hline \multirow[t]{2}{*}{8} & Same Country & $\begin{array}{c}22.24 * * * \\
(5.73) \\
\end{array}$ & $\begin{array}{l}-5.11 \\
(3.62) \\
\end{array}$ & $\begin{array}{c}8.57 * * * \\
(3.10) \\
\end{array}$ & $\begin{array}{l}-7.78 * \\
(4.50) \\
\end{array}$ & $\begin{array}{c}6.48 \\
(7.08) \\
\end{array}$ & $\begin{array}{c}-4.10 \\
(3.84) \\
\end{array}$ \\
\hline & \multicolumn{7}{|c|}{ Borrower Country Specific (except $\left.{ }^{a}\right)$} \\
\hline 9 & Creditor Rights & $\begin{array}{c}-4.74 * * \\
(2.31) \\
\end{array}$ & $\begin{array}{c}-0.38 \\
(1.09) \\
\end{array}$ & $\begin{array}{c}0.01 \\
(1.28) \\
\end{array}$ & $\begin{array}{c}0.81 \\
(0.97)\end{array}$ & $\begin{array}{l}-2.02 \\
(2.06) \\
\end{array}$ & $\begin{array}{l}-0.45 \\
(0.99)\end{array}$ \\
\hline 10 & $\begin{array}{l}\text { Creditor Rights } \\
\text { missing }\end{array}$ & $\begin{array}{l}-12.49 \\
(11.20) \\
\end{array}$ & $\begin{array}{c}4.00 \\
(5.41) \\
\end{array}$ & $\begin{array}{c}5.52 \\
(8.84) \\
\end{array}$ & $\begin{array}{l}-4.63 \\
(4.64) \\
\end{array}$ & $\begin{array}{c}-4.57 \\
(11.36) \\
\end{array}$ & $\begin{array}{c}2.16 \\
(5.15) \\
\end{array}$ \\
\hline 11 & $\log (\mathrm{GDP})$ & $\begin{array}{c}-7.35 * * * \\
(2.23) \\
\end{array}$ & $\begin{array}{c}-4.19 * * * \\
(0.76) \\
\end{array}$ & $\begin{array}{c}-5.17 * * * \\
(1.00) \\
\end{array}$ & $\begin{array}{c}-5.10 * * * \\
(0.93) \\
\end{array}$ & $\begin{array}{c}0.52 \\
(2.22) \\
\end{array}$ & $\begin{array}{c}-4.73 * * * \\
(0.69) \\
\end{array}$ \\
\hline 12 & GDP growth & $\begin{array}{l}-1.53 \\
(1.16) \\
\end{array}$ & $\begin{array}{c}1.87^{* * * *} \\
(0.51) \\
\end{array}$ & $\begin{array}{c}1.47 * * \\
(0.62) \\
\end{array}$ & $\begin{array}{c}0.76 \\
(0.53) \\
\end{array}$ & $\begin{array}{c}0.11 \\
(0.65) \\
\end{array}$ & $\begin{array}{c}1.63 \\
* * *(0.55) \\
\end{array}$ \\
\hline 13 & $\begin{array}{l}\text { Sovereign } \\
\text { Credit Risk } \\
\end{array}$ & $\begin{array}{l}-0.40 \\
(0.93) \\
\end{array}$ & $\begin{array}{c}-3.42 * * * \\
(0.73) \\
\end{array}$ & $\begin{array}{c}-1.35 * * \\
(0.53) \\
\end{array}$ & $\begin{array}{c}-3.72 * * * \\
(0.55) \\
\end{array}$ & $\begin{array}{c}1.03 \\
(1.03) \\
\end{array}$ & $\begin{array}{c}-3.36 * * * \\
(0.70) \\
\end{array}$ \\
\hline 14 & $\begin{array}{l}\text { Lender Country } \\
\text { Fin. Develop. }\end{array}$ & $\begin{array}{l}23.88 * \\
(12.55) \\
\end{array}$ & $\begin{array}{c}2.74 \\
(3.94) \\
\end{array}$ & $\begin{array}{c}-6.09 \\
(20.73) \\
\end{array}$ & $\begin{array}{c}20.23 * * * \\
(6.51) \\
\end{array}$ & $\begin{array}{c}16.44 \\
(12.67) \\
\end{array}$ & $\begin{array}{c}2.90 \\
(4.10) \\
\end{array}$ \\
\hline $\mathrm{Obs}$ & rvations & 2,186 & 39,578 & 17,180 & 23,403 & 3,520 & 38,306 \\
\hline & uared & 0.24 & 0.36 & 0.37 & 0.39 & 0.22 & 0.36 \\
\hline
\end{tabular}

${ }^{+}$Significance levels: $* * * 1 \%, * * 5 \% ; * 10 \%$ 
Table 9 -Effects on Loan Maturity of Interactions between Bank Regulations, Rule of Law, and Competition

Dependent variable: Log of Maturity. OLS regressions over the period 1998-2006. Robust standard errors clustered by banks are in parentheses. Constant, year dummies and other loan-specific controls (industry sector, loan purpose and loan type) are omitted. Coefficients and standard errors are multiplied by 100 . Significance levels: *** $1 \%$, ** $5 \%$; * $10 \%$.

\begin{tabular}{|c|c|c|c|c|c|c|}
\hline \multicolumn{2}{|c|}{ Explanatory Variables } & $R 1$ & $R 2$ & $R 3$ & $R 4$ & R5 \\
\hline & \multicolumn{6}{|c|}{ Lender Country Specific } \\
\hline 1 & Capital & $\begin{array}{c}-15.22 * * * \\
(4.76)\end{array}$ & $\begin{array}{c}-21.36 * * * \\
(5.45)\end{array}$ & $\begin{array}{c}-7.38 * * \\
(3.71)\end{array}$ & $\begin{array}{c}-15.28 * * * \\
(4.04)\end{array}$ & $\begin{array}{c}-27.23 * * * \\
(6.20)\end{array}$ \\
\hline 2 & Capital`2 $^{\wedge}$ & $\begin{array}{c}0.85 * * * \\
(0.32) \\
\end{array}$ & $\begin{array}{c}1.14 * * * \\
(0.29) \\
\end{array}$ & $\begin{array}{c}0.89 * * * \\
(0.32) \\
\end{array}$ & $\begin{array}{c}1.47 * * * \\
(0.32) \\
\end{array}$ & $\begin{array}{c}1.14 * * * \\
(0.29) \\
\end{array}$ \\
\hline 3 & Official & $\begin{array}{c}-2.04 * * * \\
(0.56) \\
\end{array}$ & $\begin{array}{c}-2.19 * * * \\
(0.59) \\
\end{array}$ & $\begin{array}{c}-1.44^{* *} \\
(0.62) \\
\end{array}$ & $\begin{array}{c}-1.79 * * * \\
(0.52) \\
\end{array}$ & $\begin{array}{c}-2.00 * * * \\
(0.57) \\
\end{array}$ \\
\hline 4 & Private Monitoring & $\begin{array}{c}0.71 \\
(0.90) \\
\end{array}$ & $\begin{array}{c}0.15 \\
(0.88) \\
\end{array}$ & $\begin{array}{c}-7.01 * * \\
(3.49) \\
\end{array}$ & $\begin{array}{c}-7.80 * * \\
(3.24) \\
\end{array}$ & $\begin{array}{c}-15.08 * * * \\
(3.99) \\
\end{array}$ \\
\hline 5 & Rule of Law & $\begin{array}{c}-43.01 * * * \\
(9.89)\end{array}$ & & $\begin{array}{c}-47.06^{* *} \\
(20.39)\end{array}$ & & $\begin{array}{c}-90.61 * * * \\
(21.06)\end{array}$ \\
\hline 6 & Competition & & $\begin{array}{c}-8.32 * * \\
(3.64) \\
\end{array}$ & & $\begin{array}{l}-8.19^{*} \\
(4.51) \\
\end{array}$ & $\begin{array}{c}-16.29 * * * \\
(6.28) \\
\end{array}$ \\
\hline 7 & $\begin{array}{l}\text { Capital x } \\
\text { Rule of Law }\end{array}$ & $\begin{array}{c}6.26 * * * \\
(1.72) \\
\end{array}$ & & & & $\begin{array}{c}4.65 * * * \\
(1.54) \\
\end{array}$ \\
\hline 8 & $\begin{array}{l}\text { Capital } \mathrm{x} \\
\text { Competition }\end{array}$ & & $\begin{array}{c}1.99 * * * \\
(0.65) \\
\end{array}$ & & & $\begin{array}{c}1.84 * * * \\
(0.66)\end{array}$ \\
\hline 9 & $\begin{array}{l}\text { Priv. Monitoring x } \\
\text { Rule of Law }\end{array}$ & & & $\begin{array}{c}4.80^{* *} \\
(2.29)\end{array}$ & & $\begin{array}{c}6.01 * * * \\
(2.00)\end{array}$ \\
\hline 10 & $\begin{array}{l}\text { Priv. Monitoring x } \\
\text { Competition }\end{array}$ & & & & $\begin{array}{l}1.39 * * \\
(0.56) \\
\end{array}$ & $\begin{array}{c}1.07 * * \\
(0.51) \\
\end{array}$ \\
\hline & \multicolumn{6}{|c|}{ Lender, borrower and loan specific } \\
\hline 11 & Lender Log (Assets) & $\begin{array}{l}-1.57 \\
(1.06)\end{array}$ & $\begin{array}{c}-4.51 * * * \\
(1.23)\end{array}$ & $\begin{array}{l}-1.61 \\
(1.10)\end{array}$ & $\begin{array}{c}-5.16 * * * \\
(1.25)\end{array}$ & $\begin{array}{c}-4.50 * * * \\
(1.25)\end{array}$ \\
\hline 12 & Lender Leverage & $\begin{array}{l}-0.88 \\
(0.76) \\
\end{array}$ & $\begin{array}{c}0.25 \\
(0.65) \\
\end{array}$ & $\begin{array}{l}-0.93 \\
(0.76) \\
\end{array}$ & $\begin{array}{c}0.60 \\
(0.66) \\
\end{array}$ & $\begin{array}{c}0.72 \\
(0.61) \\
\end{array}$ \\
\hline 13 & Borrower Rating & $\begin{array}{c}2.43 * * * \\
(0.48) \\
\end{array}$ & $\begin{array}{c}2.33^{* * *} \\
(0.44) \\
\end{array}$ & $\begin{array}{c}2.50 * * * \\
(0.49) \\
\end{array}$ & $\begin{array}{c}2.35 * * * \\
(0.45) \\
\end{array}$ & $\begin{array}{c}2.33 * * * \\
(0.43) \\
\end{array}$ \\
\hline 14 & Log (Deal Amount) & $\begin{array}{c}6.30 * * * \\
(1.09)\end{array}$ & $\begin{array}{c}6.05 * * * \\
(1.12)\end{array}$ & $\begin{array}{c}6.42 * * * \\
(1.08)\end{array}$ & $\begin{array}{c}6.15 * * * \\
(1.14)\end{array}$ & $\begin{array}{c}5.93 * * * \\
(1.14)\end{array}$ \\
\hline 15 & Same Country & $\begin{array}{l}-1.88 \\
(3.15) \\
\end{array}$ & $\begin{array}{l}-0.81 \\
(3.30) \\
\end{array}$ & $\begin{array}{l}-1.89 \\
(3.17) \\
\end{array}$ & $\begin{array}{c}-0.42 \\
(3.31) \\
\end{array}$ & $\begin{array}{l}-1.57 \\
(3.13)\end{array}$ \\
\hline & \multicolumn{6}{|c|}{ Borrower Country Specific (except ${ }^{a}$ ) } \\
\hline 16 & Creditor Rights & $\begin{array}{l}-0.42 \\
(0.90)\end{array}$ & $\begin{array}{c}0.23 \\
(0.88) \\
\end{array}$ & $\begin{array}{l}-0.03 \\
(0.87) \\
\end{array}$ & $\begin{array}{c}0.36 \\
(0.83) \\
\end{array}$ & $\begin{array}{l}-0.17 \\
(0.81)\end{array}$ \\
\hline 17 & $\begin{array}{l}\text { Creditor Rights } \\
\text { missing }\end{array}$ & $\begin{array}{c}1.41 \\
(5.06) \\
\end{array}$ & $\begin{array}{l}-0.80 \\
(4.77) \\
\end{array}$ & $\begin{array}{c}1.79 \\
(5.07) \\
\end{array}$ & $\begin{array}{l}-0.93 \\
(4.70) \\
\end{array}$ & $\begin{array}{c}0.02 \\
(4.95) \\
\end{array}$ \\
\hline 18 & $\log (\mathrm{GDP})$ & $\begin{array}{c}-4.54 * * * \\
(0.76) \\
\end{array}$ & $\begin{array}{c}-4.75 * * * \\
(0.74) \\
\end{array}$ & $\begin{array}{c}-4.39 * * * \\
(0.77) \\
\end{array}$ & $\begin{array}{c}-4.79 * * * \\
(0.75) \\
\end{array}$ & $\begin{array}{c}-5.18^{* * *} \\
(0.72)\end{array}$ \\
\hline 19 & GDP growth & $\begin{array}{c}1.59 * * * \\
(0.48) \\
\end{array}$ & $\begin{array}{c}1.48 * * * \\
(0.48) \\
\end{array}$ & $\begin{array}{c}1.60 * * * \\
(0.48) \\
\end{array}$ & $\begin{array}{c}1.60 * * * \\
(0.48) \\
\end{array}$ & $\begin{array}{c}1.55 * * * \\
(0.46) \\
\end{array}$ \\
\hline 20 & $\begin{array}{l}\text { Sovereign Credit } \\
\text { Risk }\end{array}$ & $\begin{array}{c}-3.04 * * * \\
(0.57)\end{array}$ & $\begin{array}{c}-2.72 * * * \\
(0.61)\end{array}$ & $\begin{array}{c}-2.98^{* * *} \\
(0.57)\end{array}$ & $\begin{array}{c}-2.70 * * * \\
(0.62)\end{array}$ & $\begin{array}{c}-3.13^{* * *} \\
(0.58)\end{array}$ \\
\hline 21 & $\begin{array}{l}{ }^{\text {a }} \text { Lender Country Fin. } \\
\text { Develop. }\end{array}$ & $\begin{array}{c}3.65 \\
(3.65) \\
\end{array}$ & $\begin{array}{c}13.43 * * * \\
(4.49)\end{array}$ & $\begin{array}{c}5.36 \\
(3.92) \\
\end{array}$ & $\begin{array}{c}14.09 * * * \\
(4.23)\end{array}$ & $\begin{array}{c}17.38 * * * \\
(4.39)\end{array}$ \\
\hline Obs & vations & 41,965 & 41,965 & 41,965 & 41,965 & 41,965 \\
\hline $\mathrm{R}-\mathrm{sC}$ & tared & 0.35 & 0.35 & 0.35 & 0.35 & 0.35 \\
\hline
\end{tabular}


Figure 1 - Effects on Loan Maturity of Interaction between Capital regulations and Rule of Law

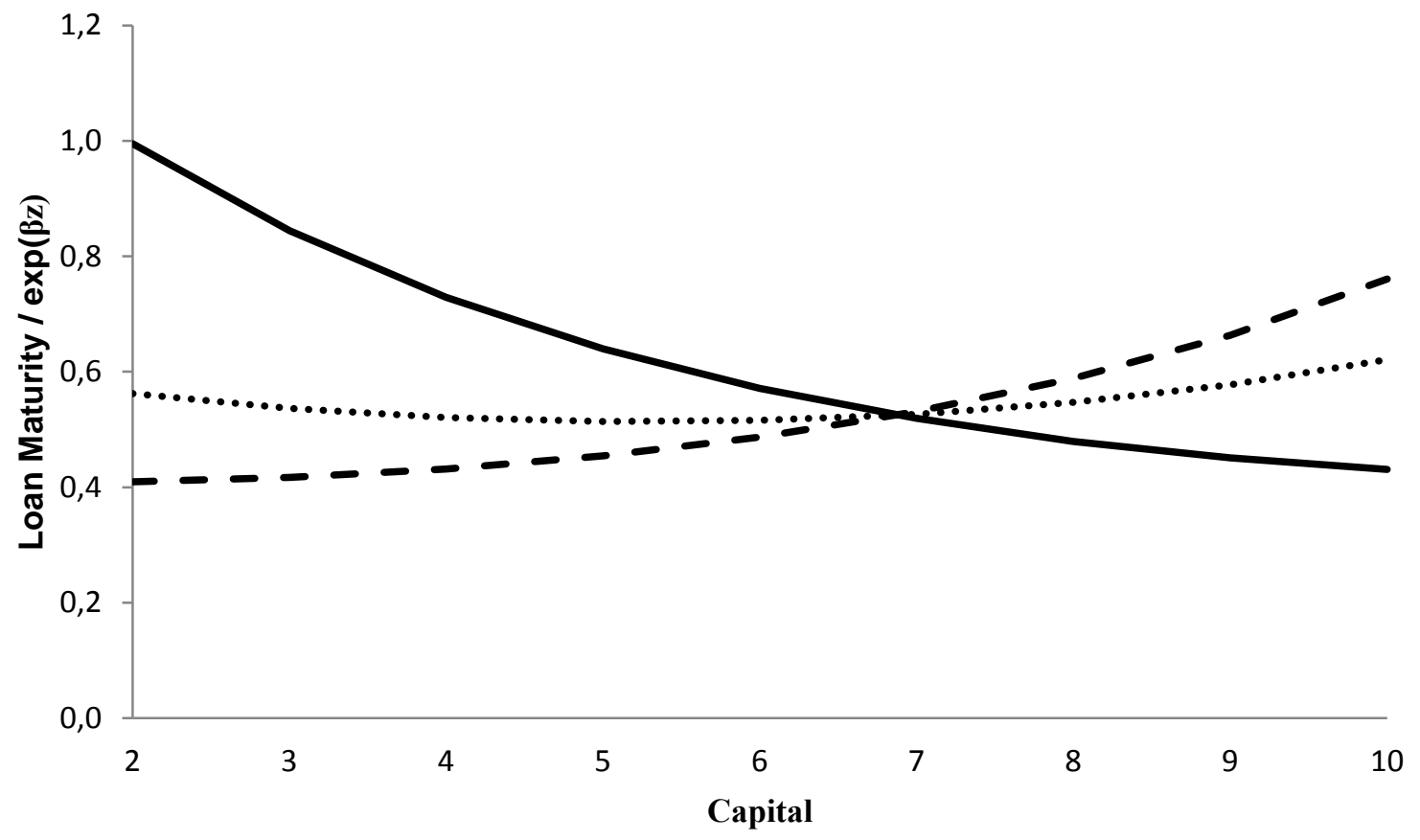

Rule of Law $=\min \quad \ldots . .$. Rule of Law $=$ mean $\quad-\quad-$ Rule of Law $=$ max

Figure 2 - Effects on Loan Maturity of Interaction between Capital regulations and Competition

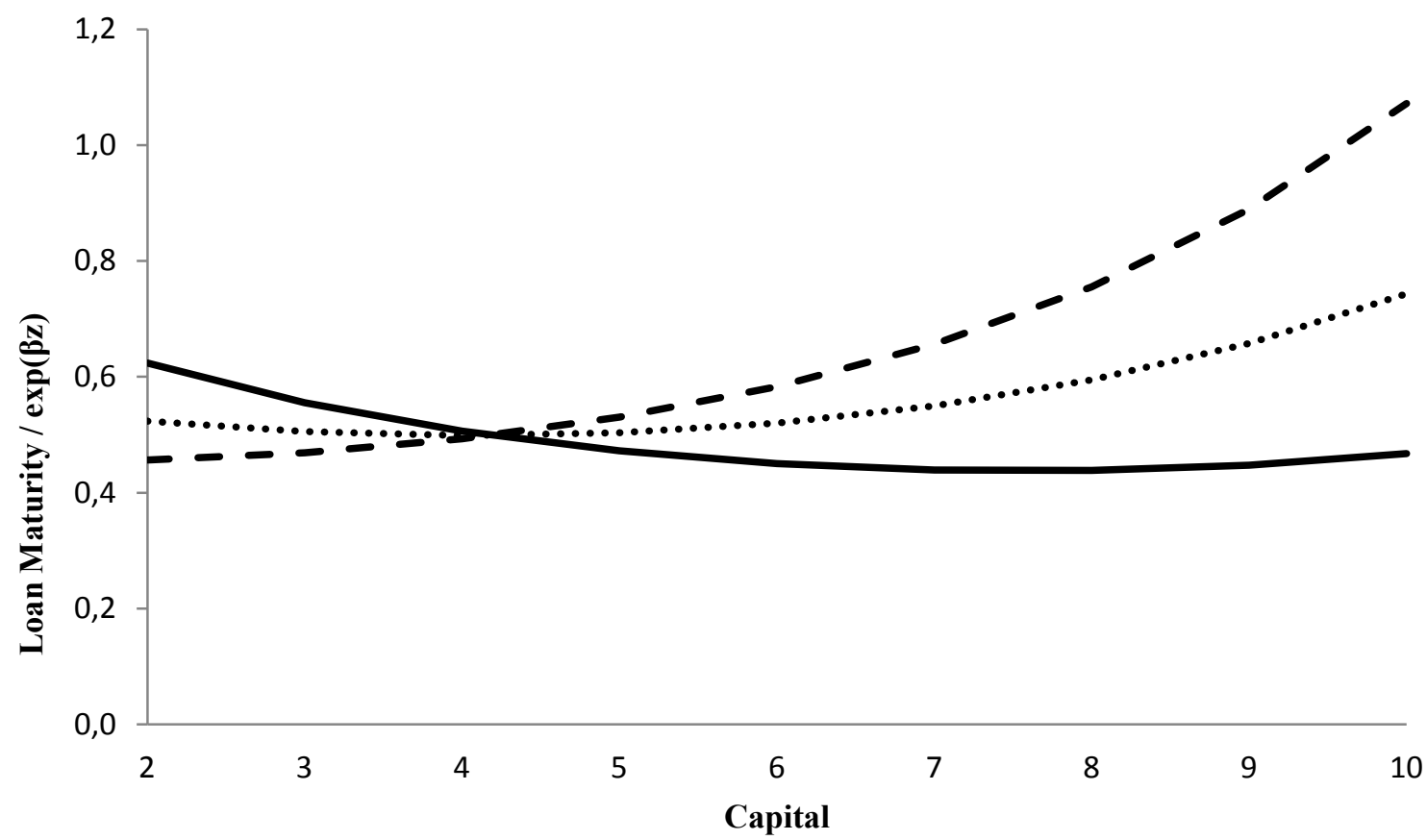

Competition $=\min \quad \ldots . .$. Competition $=$ median $\quad-\quad-$ Competition $=\max$ 
Figure 3 - Effects on Maturity of Interaction between Private Monitoring and Rule of Law

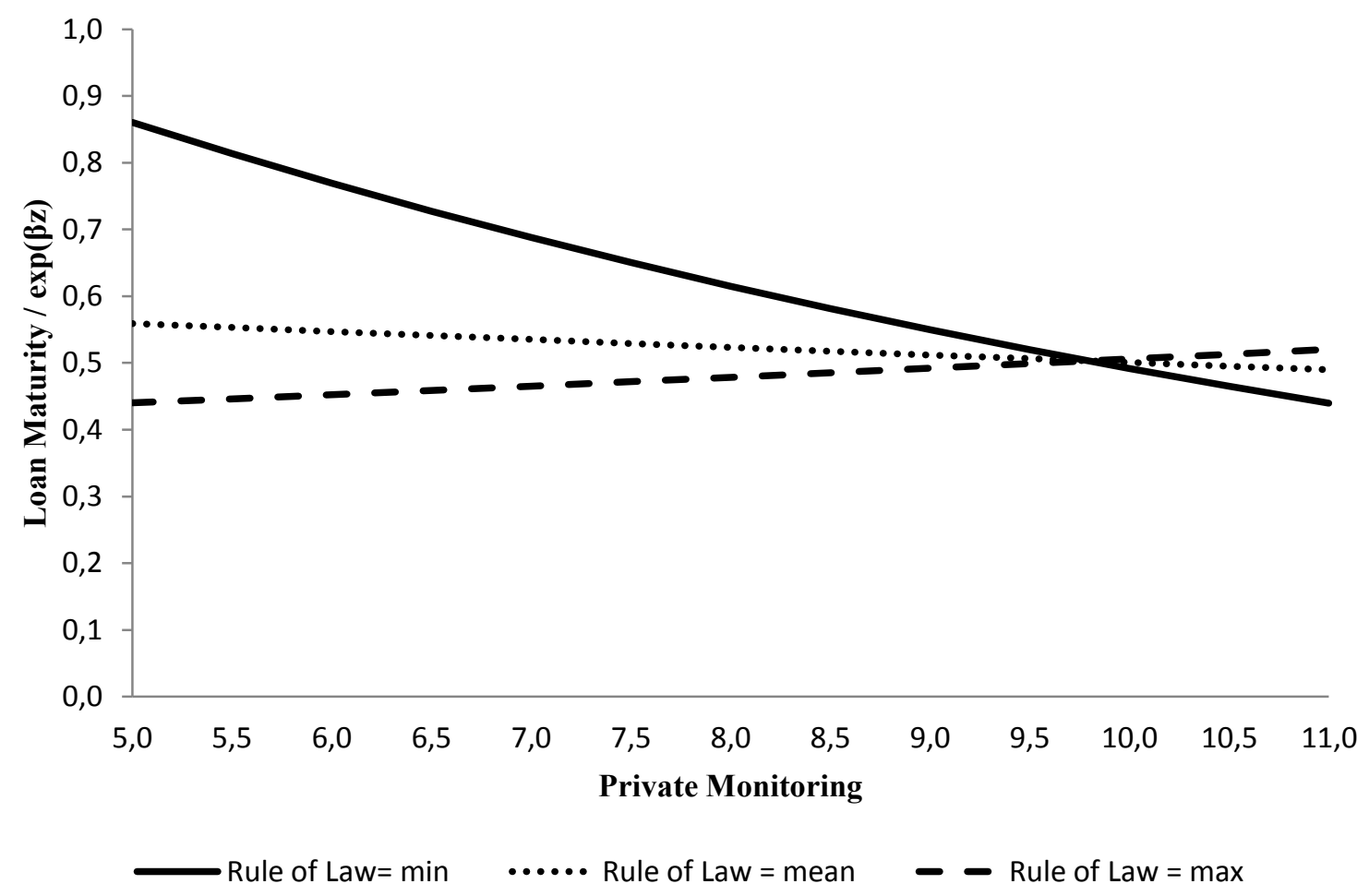

Figure 4 - Effects on Maturity of Interaction between Private Monitoring and Competition

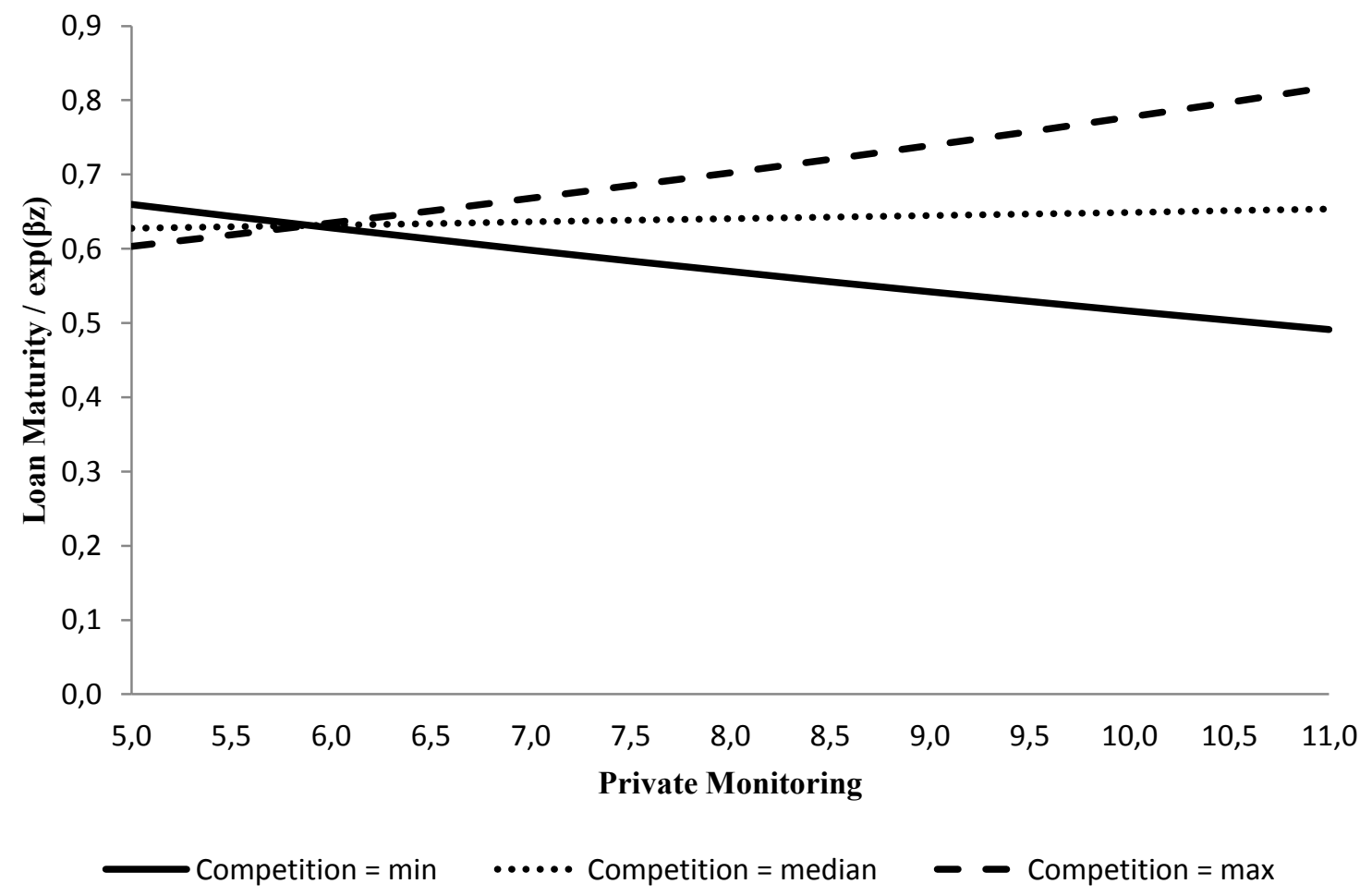

